\title{
Institutional Work: Taking Stock and Making It Matter
}

\author{
Christian E. Hampel \\ University of Cambridge \\ Thomas B. Lawrence \\ University of Oxford \\ Paul Tracey \\ University of Cambridge
}




\section{Introduction}

"Institutional work" has evolved from a concept introduced to capture a set of actions described in institutional research, to a perspective on the relationship between institutions and actors associated with a distinctive set of questions, assumptions, findings, and theoretical claims. The questions at the heart of the institutional work perspective focus on understanding how, why, and when actors work to shape sets of institutions, the factors that affect their ability to do so, and the experience of these efforts for those involved. Built into these questions are a set of assumptions: that social reality is socially constructed, mutable, and dependent on as well as embedded in the behavior, thoughts and feelings of people and collective actors. There is also a key assumption that people and collective actors have the potential to act in ways that involve an awareness of their relationship to institutions. Rather than accepting institutions as innately enduring and their effects as immutable, research on institutional work explores the practices and processes associated with actors' endeavors to build up, tear down, elaborate, and contain institutions, as well as amplify or suppress their effects. Pursuing research on institutional work has led to important findings that have identified a wide range of forms of institutional work, documented the complex interplay of different forms of institutional work (Creed, Dejordy, \& Lok, 2010; Granqvist \& Gustafsson, In press; Leung, Zietsma, \& Peredo, 2014), demonstrated the important work of actors to maintain institutions (Currie, Lockett, Finn, Martin, \& Waring, 2012; Micelotta \& Washington, 2013; Trank \& Washington, 2009), and shown the potentially powerful intended and unintended consequences of institutional work (Singh \& Jayanti, 2013; Zietsma \& Lawrence, 2010). Scholars have explored how actors employ institutional work across different levels, including individual (Tracey, In press), organizational (Gawer \& Phillips, 2013; Tracey, Phillips, \& Jarvis, 2010), community (Lawrence \& Dover, 2015; Mair, Marti, \& 
Ventresca, 2012), field (Suddaby \& Viale, 2011; Trank \& Washington, 2009) and national levels of analysis (Hirsch \& Bermiss, 2009). An important set of findings describes how the interplay of institutional work by groups of actors can lead to institutional change that combines conflicting and competing interests in newly negotiated institutional orders (Helfen \& Sydow, 2013; Helms, Oliver, \& Webb, 2012; Maguire \& Hardy, 2009; Smets, Morris, \& Greenwood, 2012; Zietsma \& Lawrence, 2010).

The institutional work perspective has, we argue, shifted the conversation around institutions and organizations, both within the confines of the institutional work literature and more broadly across organizational institutionalism: it has been a significant catalyst for the integration of a practice perspective on institutions (see chapter by Smets and Whittington in this handbook), greater attention to "micro" institutional concerns (though we will argue that this may be at the cost of understanding the institutional work to influence large institutions; see chapter by Powell and Rerup, a renewed concern for politics and contestation in institutional change (see chapter by Lawrence and Buchanan), and especially a deeper, more nuanced investigation of the relationship between agency and institutions. As research on institutional work has progressed, the perspective has also acted as a gateway to introduce or extend new concerns for institutional scholars, including the relationship between emotions and institutions (Creed, Hudson, Okhuysen, \& Smith-Crowe, 2014; Voronov \& Vince, 2012; see also the chapter by Lok, Creed, DeJordy and Voronov in this handbook), the lived experienced of institutional life (Creed et al., 2010; Tracey et al., 2010), the interplay of institutions and materiality (Jones \& Massa, 2013; Lawrence \& Dover, 2015; Raviola \& Norbäck, 2013; see also the chapter by Jones, Meyer, Jancsary and Höllerer in this handbook), the oppressive potential of institutions (Creed et al., 2010; Martí \& Fernández, 2013; Tracey et al., 2010), and the connection between changes in 
fine-grained practices and larger institutions (Jarzabkowski, Matthiesen, \& Van de Ven, 2009; Smets \& Jarzabkowski, 2013).

\section{Theoretical Foundations of Institutional Work}

Originally defined as "the purposive action of individuals and organizations aimed at creating, maintaining and disrupting institutions" (Lawrence \& Suddaby, 2006: 215), institutional work contrasts with most other institutional approaches by placing the spotlight on the role of actors and their efforts to interact with and influence institutions. The study of institutional work is founded on two primary theoretical ideas. The first is embedded agency (Battilana \& D'Aunno, 2009), which from an institutional work perspective is less a paradox than simply a description of how people confront institutions on a day-to-day basis (Creed et al., 2010; Leung et al., 2014). From an institutional work perspective, institutions shape every facet of human existence, providing meaning and motivation to our actions, and holding together the material and symbolic structures that trigger and shape those actions; at the same time, however, institutions are ongoing human accomplishments, constructed and maintained by people's behavior, thoughts and feelings, often in ways that are unreflexive and unintended, but just as often in ways that reflect people's institutional awareness, their desires to affect institutional arrangements, and the skills and resources they marshal to achieve those desires. The idea of embedded agency has become a part of nearly all research on institutions and organizations, but it is at the heart of the institutional work perspective. The location of embedded agency in the institutional work perspective builds directly on the foundational writing of DiMaggio (1988) and Oliver $(1991,1992)$ that clarified the need to integrate a sophisticated and heterogeneous understanding of agency when considering the relationship between institutions and organizations. An important move in the institutional work literature beyond these foundations 
has been to explore the whole gamut of outcomes of actors' work, including achieving one's objectives, failing at them, and triggering unintended consequences.

A second key concept for the institutional work perspective is the idea of practice. The study of institutional work draws significantly on the sociology of practice that has been an important part of the broader practice turn in the social sciences (De Certeau, 1984; Giddens, 1984; Schatzki, Knorr-Cetina, \& Von Savigny, 2001; Whittington, 2006). In this tradition, practices represent "embodied, materially mediated arrays of human activity centrally organized around shared practical understanding" (Schatzki et al., 2001:2). Practice-theoretic approaches to social life bring with them a specific ontology within which "phenomena of various complexities are not made of transcendental elements such as forces, logics or mental models. When it comes to the social world, it is practicing all the way down" (Nicolini \& Monteiro, In press). Although this may seem like an extreme position, it brings with it the potential for fantastic theoretical clarity. The institutional work perspective relies heavily on the concept of practice as a bridge between people's reflexive, purposive efforts and the institutions at which those efforts are aimed: concrete instances of institutional work are simultaneously practices - embodied, materially mediated arrays of human activity - that are organized around institutions and people's intentions to shape those institutions. Thus, the institutional work perspective builds on the sociology of practice by focusing on particular sets of practices aimed at affecting the institutional arrangements within which they are situated. In so doing, institutional work encourages a shift in attention from field-level patterns, to the specific practices that underpin them, and at the same time offers a path along which institutional and practices scholars might enjoy a shared journey and benefit from the strengths of each other's approaches. 


\section{Our aims in this chapter}

Three main aims motivate this chapter. First, we aim to take stock of the institutional work perspective as it has developed since 2006. We limit our review to research that has explicitly adopted the "institutional work" label, rather than including all research concerned with the relationship between agency and institutions more broadly. So, for instance, although research on social movements, hybrid organizations, and paradox examines forms of social action that could be understood from an institutional work perspective, we leave a discussion of those literatures to others (including other chapters in this Handbook - see Schneiberg and Lounsbury, and Battilana, Besharov, Mitzinneck). We also realize that our review overlaps with Hardy and Maguire's review of institutional entrepreneurship in this volume, and so we leave a detailed exploration of the concept to their chapter. Our first aim of taking stock is represented by the chapter's first main section, which investigates the institutional work literature in terms of "what" (the institutions highlighted in research on institutional work), "who" (the actors on which institutional work research has focused), and "how" (the strategies through which actors influence institutions).

Our second aim is to highlight what we see as important gaps in the development of the institutional work perspective, focusing in particular on the "what", "who" and "how" of institutional work. With respect to "what", we found an important gap in our understanding of institutional work aimed at large-scale institutions. A consistent focus in institutional work research has been on how actors influence what might be described as "middle-range" institutions - institutionalized beliefs, rules and values that exert a significant influence within an organization, community or field. This is despite dramatic shifts in such large-scale institutions over the past few decades, much of which has been the result of intentional, effortful work by a 
wide range of individuals, groups, organizations and networks. The second gap we address concerns "who" - the range of actors that research on institutional work has included. Largely missing in research to date has been the collaborative work of heterogeneous networks of actors, which may be especially important in institutional work that is concerned with shaping largescale institutions. The third gap we examine concerns "how" institutional work is done. Despite a range of studies that have explored a wide variety of strategies for institutional work, there has remained a focus on symbolic forms of institutional work, at the expense of understanding the role of relational and material forms. For each of these gaps, we explore an allied literature that we believe could provide theoretical and methodological insights that would provide insight and energy if integrated into the institutional work perspective.

Our third aim in this chapter is to use the study of institutional work to move organizational institutionalism toward a more practical, impactful connection with audiences outside of the academy. Thus, in the paper's final main section, we explore the possibility of an applied program of institutional work research. We approach this challenge first by examining the potential for institutional work research to shift towards a focus on institutions "that matter" - institutions tied to major social challenges. We then explore two ways in which an applied program of institutional work research might be constructed: as a policy science; and as a form of participatory action research. We argue that an applied program of institutional work would provide an important practical, prescriptive addition to the current focus on theoretical novelty and empirical precision. It would, however, necessitate broad changes to the way we conduct research projects, interact with policy-makers, and conceptualize our relationships with those we study. We encourage scholars to use and develop institutional work to tackle the challenges surrounding the institutions that matter. 


\section{The institutions in "institutional work"}

The question of what kinds of institutions are examined in research on institutional work is a complex one. A common way to differentiate institutions in organizational research is in terms of the particular form they take - such as practices (Hiatt, Sine, \& Tolbert, 2009; Lok \& de Rond, 2013), boundaries (Åkerström, 2002; Zietsma \& Lawrence, 2010), values (Gehman, Trevino, \& Garud, 2013; Wright, Zammuto, \& Liesch, 2015), rules (Heaphy, 2013), or standards (Slager, Gond, \& Moon, 2012). In strategy and international business, a more common categorization focuses on formal versus informal institutions (Peng, Wang, \& Jiang, 2008; Stiglitz, 1999). In looking across the research on institutional work, we found studies that incorporated all of these different kinds of institutions.

An important, but under-examined, basis for differentiating studies of institutional work

is the "level" of the institution that is the target of institutional work. The issue of levels is a surly one in organizational institutionalism. Some scholars posit a distinctly institutional level, often focusing on the rules, practices and beliefs institutionalized across societies or fields. By contrast, others suggest that institutions can exist at any level of analysis, including the organization, group and individual levels. In reviewing the literature on institutional work, it is apparent that there has been a clear tendency to focus on the field- and organization levels. Indeed, 44 out of the 53 studies in our review fall into this category.

\section{Field-level Institutions}

Following DiMaggio and Powell's (1983) lead and mirroring institutional theory more broadly, research on institutional work has often focused on characteristics of fields as the main target for institutional work. The concept of a field is, of course, a contested one (see Hoffman and Wooten, this volume). Broadly defined as "a community of organizations that partakes of a 
common meaning system and whose participants interact more frequently and fatefully with one another than with actors outside the field" (Scott, 1995:56), fields have been the focus of a vibrant stream of research that examined the institutional work associated with efforts to create, maintain and transform them. Studies have shown the challenges that field actors face in finding agreement for the internal arrangements of the field: they need to decide which roles to allow, which practices to adopt, and which logics to follow (e.g., Jones \& Massa, 2013; Wright \& Zammuto, 2013a; Zietsma \& McKnight, 2009a). In terms of external work, studies have shown that actors need to build or maintain the field's legitimacy, its boundaries, and its relations to other fields (Boxenbaum \& Strandgaard Pedersen, 2009; Riaz, Buchanan, \& Bapuji, 2011). These actions are vital to secure the continued support from key resource providers, such as regulators, the media, or investors, many of which are usually external to the field.

By far the most commonly examined object of institutional work has been field-level practices -34 of the 53 studies that we review here fall into this category. Indeed, investigations of how actors affect the status of field-level practices have been a consistent focus for institutional work research throughout the past decade. In looking across these studies, it is interesting to observe that researchers have continued to dedicate more attention to the creation and maintenance of practices, rather than to their disruption (some notable exceptions, such as, Maguire \& Hardy, 2009, notwithstanding). Early examples include Perkmann and Spicer's (2008) analysis of the institutionalization of management fashions, in which the authors identified three forms of institutional work - political work, technical work and cultural work and showed that the advocates of such fashions are more likely to be successful in institutionalizing them when they increase the types of institutional work that they deploy and when the skill sets of the actors involved are heterogeneous. Another early study of institutional 
work aimed at field-level practices was Zietsma and McKnight's (2009b) analysis of the efforts of actors in the $\mathrm{BC}$ coastal forestry industry to promote competing proto-institutions in the face of contestation. They find that actors in contested fields often need to collaborate with the proponents of opposing ideas to jointly co-create novel solutions that can protect them against external attacks. More recently, institutional work research has examined field-level practices in a range of contexts including financial services regulation (Riaz et al., 2011), micro-finance (Dorado, 2013), architecture (Jones \& Massa, 2013), capital markets (Clark \& Newell, 2013), and housing (Lawrence \& Dover, 2015).

Roles constituted the second most commonly studied field-level object of institutional work. The study of roles as objects of institutional work emerged later than the study of practices and has focused primarily on professional roles, including changes in the role identities of nurses from 1955 to 1992 (Goodrick \& Reay, 2010), efforts to maintain power by elites in response to the emergence of new roles in the UK healthcare system (Currie et al., 2012), the institutional work of pharmaceutical companies to control internal professional staff (Singh \& Jayanti, 2013), the strategies of Italian professionals to maintain the power and privileges associated with their roles (Micelotta \& Washington, 2013), and the institutional experimentation inside accounting firms struggling to define the role of auditors in the wake of financial and professional crises (Malsch \& Gendron, 2013). The interest in professional roles as objects of institutional work follows a long tradition of examining professions as arenas of institutional change (Greenwood, Suddaby, \& Hinings, 2002; Kitchener \& Mertz, 2012; Scott, Ruef, Caronna, \& Mendel, 2000). Research that has focused specifically on professional roles has added important nuance to our understanding of institutional work dynamics in these domains by explaining how and why professionals work to effect or resist change. For example, in Ramirez's (2013) study of the 
British audit profession, the trigger for institutional work was a perceived injustice stemming from institutional change that threatened the sense of "equity in a community of peers": in an effort to increase accountability in the audit profession, the professional body introduced a monitoring scheme that created an "uproar" among the smaller firms.

A third field-level institution examined in institutional work research is the organizational form - "archetypal configuration of structures and practices given coherence by underlying values regarded as appropriate within an institutional context" (Greenwood \& Suddaby, 2006a:30). Despite organizational forms being a long-standing concern in institutional theory and organizational research more broadly (Child \& McGrath, 2001; Davis, Diekmann, \& Tinsley, 1994; DiMaggio, 1991), there have been relatively few studies of the institutional work associated with their creation, and none of their disruption or maintenance. The small number of institutional work studies that has focused on organizational forms have shown that they require specific types of work to become legitimate, with co-operation between like-minded organizations especially important (e.g., Empson, Cleaver, \& Allen, 2013; Perkmann \& Spicer, 2007; Tracey, Phillips, \& Jarvis, 2011). For example, David, Sine and Haveman (2013) showed that collective action amongst related firms and relationships with high profile actors such as prestigious universities, played a key role in the emergence of management consulting as a new organizational form.

A small set of institutional work studies have examined the efforts of actors to affect standards and standard-setting processes. Standards represent mechanisms of control that "facilitate coordination by defining the appropriate attributes of the standardized subject, rendering these aspects visible to external inspection and opening up the possibility of sanctioning non-compliance" (Slager et al., 2012: 765). Despite much public and scholarly 
discussion of the increasing roles that standards play in contemporary society, the institutional work that goes into their formation has been relatively neglected. The research of Slager, Gond and Moon (2012) on the creation of the FTSE4Good index, which "emerged as a standard for socially responsible corporate behaviour", and of Helfen and Sydow (2013) on global labour standards shows that the institutional work underpinning such standards involves a combination of forms undertaken in complex, collaborative and competing relationships. Standards provide a particularly useful context for studying institutional work because of the public and often heated contests and debates that occur around them, which expose the varied institutional strategies used by interested actors.

Although a range of other field-level institutions exist, the bulk of institutional work research has focused on the practices, roles, organizational forms and standards described above. A minority of studies, however, have examined the institutional work associated with more varied institutions, including social boundaries (Zietsma \& Lawrence, 2010), values (Wright et al., 2015), discourses (Zilber, 2007), network configurations (Bertels, Hoffman, \& DeJordy, 2014), and field-level logics (Gawer \& Phillips, 2013). The paucity of research on these objects of institutional work is unfortunate because they all represent key facets of organizational fields.

One of the most notable - and perhaps disappointing - outcomes of our review is the lack of attention to field-level logics as potential targets of institutional work. This is especially surprising given the significant interest that institutional scholars have paid to logics more broadly (see Ocasio, Thornton and Lounsbury in this volume). Institutional logics are frames of reference through which actors make sense of the world, construct their identities, and interact with the world around them (Thornton, 2002; Thornton, Ocasio, \& Lounsbury, 2012). Thus it is clearly very important to explore how logics can be shaped by institutional work. Gawer and 
Phillips (2013) is a rare example of a study that considers how actors affect field-level logics. These authors documented the strategies through which Intel introduced the platform logic into the semiconductor field to replace the traditional supply chain logic. Importantly, they show that change in field-level logics may require simultaneous internal work at the organizational level to change local identities and practices, and external work at the field level to change field-wide practices and build legitimacy (see also Tracey, Phillips and Jarvis, 2011). We return to this issue in the next major section when we discuss gaps in our understanding of institutional work.

\section{Organization-level institutions}

Although not as abundant as research on institutional work that targets field-level institutions, there has also been a significant number of investigations of institutional work focused on organization-level institutions, including organizational practices, logics, values, and rules (Daudigeos, 2013; Rojas, 2010a; Van Wijk, Stam, Elfring, Zietsma, \& Den Hond, 2013; Zilber, 2009). The practical and political effects of organization-level institutions often lead to ongoing negotiations which result in oscillations between peaceful co-existence and conflictridden clashes. Consequently, some organization-level institutions are associated with frequent breakdowns and breaches, and thus work to repair and restore their status and legitimacy (Bjerregaard \& Jonasson, 2014; Heaphy, 2013; Lok \& de Rond, 2013). Two kinds of institutions have been particularly prominent in institutional work research: rules and logics.

Rules - both formal and informal - matter in organizations. They motivate, facilitate and constrain behavior, and they help shape the construction of organizational history and culture (March \& Olsen, 1976; Zhou, 1993). Rules also distribute resources and provide or limit opportunities for organizational members, and thus act as both the incentive and means for institutional work aimed at their maintenance or transformation (Heaphy, 2013; Raviola \& 
Norbäck, 2013). The institutional work of members to influence organizational rules includes a wide array of possibilities. One particularly radical form of institutional work in this regard involves acquiring sufficient power to change the rules. This kind of work is at the center of Rojas' (2010a) study of how the president of San Francisco State College responded to the 1968 Third World Strike, namely by using the dramatic situation to gain more powers and create draconian new rules as well as stricter punishments. A small number of studies has also looked at the maintenance, rather than the transformation, of organizational rules. Most notably, Heaphy (2013) explored how staff at US teaching and veteran hospitals struggled to treat patients in the face of physical threats that seemed to nullify formal rules. This study focused on the important role of patient advocates, who helped hospital staff by providing them with strategies so that they could protect themselves in such situations.

Finally, a third form of institutional work in relation to organizational rules involves amending particular rules while maintaining the spirit underlying them. Such an approach might prove especially appropriate in cases where rules represent sources of conflict or disagreement. Lok and de Rond (2013), for example, describe such a situation in their study of the Cambridge University Boat Club. An informal but important Club rule declared that members were to devote all their efforts to the shared goal of beating Oxford University in the annual rowing competition. But, in 2007, the crew's most experienced coxswain made the controversial and unexpected decision to train for the varsity boxing team at the same time as training with the rowing team. Lok and de Rond (2013: 198) describe how the situation triggered "negotiation work between Russ and the squad to come to an acceptable working agreement that fell outside of the scope of the normal selection script". This negotiation work served to contain the breach and thus preserve the sanctity of the informal commitment rule. 
Very different institutional work is needed in novel situations, in which actors are confronted with new activities. While conflict about existing rules has been the subject of some scholarly attention, we know very little about the work involved in deciding how new domains should be governed, the processes underpinning the creation of these rules, and how new rules interact with prevailing ones. Raviola and Norbäck (2013) suggest that in such situations actors can try to identify existing rules in analogous domains of activity and transfer them to new situations. For example, when negotiating the new domain of online newsmaking, Italian journalists were able to draw on the rules supporting the print edition of their newspaper as a 'law book' to guide the behavior of organizational members and help them adjust. This study also highlights that the cautious adaptation and selective application of existing rules provides actors with a non-confrontational approach through which they can navigate institutional challenges and employ rules to their own advantage (see also Seo \& Creed, 2002).

Although institutional logics are more typically thought of as field-level or societal phenomena, a small number of studies have shown that logics can represent the targets of organization-level institutional work. These studies take the perspective that institutional logics are "constructed rather than given" (Smets \& Jarzabkowski, 2013: 1279) inside organizations. Logics may be grounded in extra-organizational structures and cultures, but to be meaningful and impactful in organizations they need to be made local - rendered interpretable and actionable in the face of organizational routines, structures, values, beliefs and relationships. This dynamic is especially visible in the context of institutional complexity, where organizational members struggle with the concurrent impact of multiple competing logics, such as the market logic and the family logic, in the same organization (Greenwood, Raynard, Kodeih, Micelotta, \& Lounsbury, 2011; Kraatz \& Block, 2008). Although organizational responses to institutional 
control has emerged as a vibrant research domain, relatively few studies (e.g., Smets, Jarzabkowski, Burke, \& Spee, 2015; Toubiana \& Zietsma, forthcoming) have drawn on the concept of institutional work to tackle this thorny challenge. One such exception is Jarzabkowski, Matthiesen, and Van de Ven's (2009) study of institutional complexity in a utility firm whose members sought to reconcile opposing market and regulatory logics through a wide array of institutional work. Interestingly, this study showed that organizational members can engage in different types of seemingly conflicting institutional work simultaneously - creation work was used to augment certain aspects of the logics inside the firm, while disruption work was used to contest other aspects. More broadly, research on institutional work directed at shaping logics inside organizations has illustrated various approaches to tackling this issue, including slowly integrating emerging logics into an established logic, combining multiple logics, and continuously recalibrating the relationship between existing logics (Bjerregaard \& Jonasson, 2014; Empson et al., 2013; Smets \& Jarzabkowski, 2013; Tracey et al., 2010) These studies highlight two important, broader phenomena within institutional work research at the organization-level: first, scholars make increasingly explicit and prominent use of practice-theory for explaining institutional work, and second, scholars increasingly suggest that the process and outcomes of institutional work may differ. Thus, while actors are usually concerned with only one institutional outcome (creation, maintenance or disruption), they often need to draw on all three institutional work processes (creation, maintenance, and disruption) to achieve that outcome - as Jarzabkowski, Matthiesen, and Van de Ven (2009), among others, have shown. 


\section{Individuals and Institutions}

The relationship between individuals and institutions could be central to the study of institutional work if one follows Giddens (1984) and Bourdieu (1998) who locate social structure in the memory traces of individuals. This perspective suggests that actors can engage in a critically important form of institutional work by shaping the memories (and identities and emotions) of individuals, including their own. Despite the tremendous potential, and the repeated calls for scholars to investigate the micro-foundations - the coalface - of institutions, relatively little research on this kind of institutional work has been undertaken. An exception is Tracey's (In press) study of the Alpha course, "an evangelizing movement designed to convert agnostics to a particular - and contested - interpretation of Christianity". This study asks how organizations persuade individuals to internalize a new logic, and documents four key kinds of “micro-institutional work" (framing work, identity work, affective work, and performative work). A key finding of this study is the precariousness of such institutional work: Tracey argues that effectively enacting "these forms of work is challenging and requires high levels of skill", and that even then, "the outcomes of the persuasive process uncertain - conversion is by no means guaranteed".

The institutional work connecting individuals and institutions has also been explored as a "bottom up" phenomenon, in which people experience their identities as in conflict with or constrained by broader institutions, and consequently engage in institutional work to reclaim, redefine or justify their identities (Creed et al., 2010; Leung et al., 2014). Creed, DeJordy and Lok (2010), for example, found in their study of GLBT ministers that individuals can use embodied identity work to reconcile clashes between their identity and dominant institutions. The GLBT ministers in this study used self-narratives based on salient experiences to justify 
their institutional role and challenge their marginalization. Although these studies have begun to show how actors can work to accommodate their own identities in different institutional settings, the forms of work needed to resist or shed identities that result from institutional pressures have not yet been subject to systematic analysis.

More broadly, the first steps towards individual-level studies highlight various intriguing possibilities for moving institutional work research forward. First of all, they are starting to explore the important - and mostly overlooked - role that emotions play when actors interact with institutions. Second, they also alert us to the vastly different forms of commitment that individuals have to institutions - from ardent support to lukewarm compliance - and suggest scope for interesting research into why individuals increase or decrease their commitment to institutions.

\section{Societal Institutions}

We have discussed how research on institutional work has made significant advances in understanding efforts to shape field- and organization-level institutions, and some progress on understanding institutional work that targets individuals. Institutional work designed to shape societal institutions, however, has been a distinct blind spot. Only six of the 53 papers in this review focus on institutions that can reasonably be described as being anchored at the societal level. What these papers bring to the conversation around institutional work is a consideration of institutions that are often more complex and distal than the simpler, more proximal institutions located in fields and organizations.

Hirsch and Bermiss (2009), for example, explore how actors in the Czech Republic used preservation work to maintain the old societal rules, while transitioning into the emerging postCommunist economic system. During this period, the Czech Republic privatized the majority of 
state-owned enterprises and appeared to move to an economy of market-driven enterprises with dispersed ownership. In practice, however, many of the enterprises were controlled by Investment Privatization Funds, which in turn were under the influence of state-owned banks. Thus, the old rules of state-planned enterprise remained in force, despite a seemingly smooth transition to a market economy. This study highlights the complexity faced by actors when seeking to influence societal institutions, and suggests that institutional workers operating in this context need to be particularly skilled at negotiating countervailing forces. In a study focused on a very different set of dynamics, Dacin, Munir and Tracey (2010) examine a long-standing societal institution in British society - the class system. These authors show how formal dining rituals in Cambridge colleges contribute to the maintenance of social class structures in Britain. Specifically, the repeated performance of these rituals legitimate for participants the concept of social stratification, transform (or in some cases reinforce) the self-perception of Cambridge students, and elevate their social position by providing access to (and a sense of identification with) an elite professional-managerial class. A third example of institutional work aimed at societal institutions is Wijen and Ansari's (2007) research on the creation of the Kyoto Protocol. This study suggests a key challenge facing actors seeking to influence societal institutions involves uniting large numbers of diverse actors, which requires distinctive types of institutional work, such as the construction of "enrolling bandwagons" in order to recruit rapidly a critical mass of supporters.

Taken together, these studies offer only preliminary insights into the distinctive dynamics of institutional work at the societal level. But they also reveal the gaps in our knowledge and highlight the importance of, and potential for, additional research in this area - societal-level institutions arguably exert greater influence on social behavior compared to institutions at the 
meso- and micro- levels. Intriguingly, existing studies suggest that actors may be able to use forms of institutional work that have been shown to be effective at other levels of analysis for the maintenance of societal institutions (e.g., Dacin et al., 2010) but that they may need to deploy distinct types of work to create or disrupt them (e.g., Mair \& Marti, 2009; Wijen \& Ansari, 2007). This insight offers an interesting initial direction for future institutional work research at the societal level.

In sum, this section has shown that our understanding of institutional work directed at institutions operating at different levels of analysis is uneven. The societal-level arguably offers most promise for future research given the limited attention it has received to date and the sheer scale of the influence on social behavior exerted by institutions at this level. Clearly, however, there are many important issues that would benefit from sustained research attention across the levels that we have considered.

\section{The actors: Who engages in institutional work?}

The second question we use to structure our review of the institutional work literature focuses on the actors - the people, organizations and networks that engage in institutional work. This question is an important one because different constellations of actors have been shown to face different challenges and opportunities, experience different emotions and conflicts, and are able to achieve different institutional outcomes. The early institutional studies that underpinned the development of institutional work as a concept focused primarily on individual people and organizations, and especially those conceived of as institutional entrepreneurs who marshal resources to shape institutions in a way that furthers their interests (Battilana, Leca, \& Boxenbaum, 2009; Garud, Jain, \& Kumaraswamy, 2002; Greenwood \& Suddaby, 2006b; Maguire, Hardy, \& Lawrence, 2004a), a tendency which shaped much of the work since 2008 as 
well. Institutional work scholars have often explored how individual actors influence the institutions under whose influence they find themselves - a phenomenon known as "the paradox of embedded agency" (Seo \& Creed, 2002). This stream of research describes individual actors engaging in progressive bottom-up change, building subject positions, and drawing on broader societal elements in order to achieve their goals (Maguire, Hardy, \& Lawrence, 2004b; Rojas, 2010a; Tracey et al., 2011). For example, in their study of the creation of a new hybrid organizational form that bridged for-profit retailing and non-profit charity, Tracey, Phillips and Jarvis (2010) show how institutional entrepreneurs can leverage emerging macro-cultural discourses. In their case, the two proponents drew on increased public acceptance for social enterprises and for responsible business to establish their type of organization. Much of the research about institutional entrepreneurs has (at least implicitly) adopted a strong form of Swidler's (1986) "culture-as-a-toolkit" perspective that treats cultural elements as resources to be used for change, while downplaying the concomitant constraints that impede agency.

Despite its roots in the study of institutional entrepreneurship, one of the key elements of the institutional work agenda has been to move away from the somewhat heroic notions of institutional entrepreneurship, to a more social image of actors and agency - one that was variously more fragmented, distributed, partial, and collective. This move was a reaction to the image of "hypermuscular institutional entrepreneurs" (Lawrence, Suddaby, \& Leca, 2009:1) who were singularly able to transform what seemed for others to be intractable institutional structures (Battilana et al., 2009). Thus, a second set of institutional work studies has explored the efforts of relatively similar groups of actors, who were usually drawn from the same field of activity and shared similar interests. Indeed, 40 of the 53 studies in our review fall into this category. This research shows that relatively homogeneous groups can influence institutions by 
engaging in collective action, adopting favorable social positions, and enacting desired practices in the face of resistance (Clark \& Newell, 2013; Currie et al., 2012; Dorado, 2013). The relatively homogeneous actor groups in institutional work research primarily fall into two categories.

One set of studies explores groups of homogeneous actors who engage in institutional work within a specific organization. In contrast to field-level groups, coalitions of organizational actors tend to focus inwards by negotiating intra-organizational practices and aligning their own identities with their roles. In so doing they often affect how the organization relates to its broader institutional environment (e.g., Daudigeos, 2013; Jarzabkowski et al., 2009; Leung et al., 2014). Lok and de Rond's (2013) study of the Cambridge University Boat Club is a case in point. The homogeneity of the actor group helped to ameliorate conflict relating to the Club's goal of defeating Oxford University. Nonetheless, conflict still ensued as actors disagreed about the best approach and level of commitment for achieving this goal - a common phenomenon among homogenous actor groups (e.g., Jarzabkowski et al., 2009; Zilber, 2009).

Another set of studies about homogenous actors explores highly organized groups within a specific field; this set is dominated by professionals, such as nurses and lawyers (e.g., Empson et al., 2013; Micelotta \& Washington, 2013; Rainelli Weiss \& Huault, In press). These groups of actors are often concerned with protecting jurisdictional claims, fending off challenges to their field, and adapting their roles to new situations (e.g., Currie et al., 2012; Trank \& Washington, 2009). For example, Currie, Lockett, Finn, Martin and Waring (2012) study how specialist doctors in the English NHS were able to neutralize the status threat that resulted from the introduction of a new role. These elite actors used their command of resources and control over service delivery to shape the new role to their benefit and to co-opt actors from other 
professional groups to support them. This study highlights a key theme among studies of homogeneous actor groups: these - usually professional - actors can employ their privileged positions, power and status to maintain and extend their interests. This parallels the 'Matthew effect' - the idea that the 'rich get richer' and 'the poor get poorer' as the advantages of a favorable starting position compound evermore (Merton, 1968). However, institutional work research has yet to systematically explore the circumstances under which homogeneous groups (of professionals) can see their sphere of influence curtailed, their practices removed, and their status demoted. Thus many interesting research opportunities exist for exploring the limits of professional power.

The third main set of actors upon which institutional work scholars have focused are heterogeneous actor groups, usually from different fields of activity characterized by different and often divergent - objectives. A notable feature of these studies is that the actors on which they focus are nearly always engaged in significant, and sometimes dramatic, conflicts with one another (e.g., Zietsma \& Lawrence, 2010). Maguire and Hardy (2009), for instance, explore how scientists and activists went on the offensive to successfully de-legitimate the use of DDT in the face of widespread industry opposition. This study highlights that conflicts between heterogeneous actors are often decided by actors' ability to overcome power imbalances and challenge widely accepted institutional norms.

Interestingly, studies that concern heterogeneous actor groups who are in conflict tend to focus mainly on one side of the conflict - usually the 'winning' side. While this may be an inevitable consequence of data access constraints, the result is that these studies often emphasize one perspective of a struggle to the detriment of others, which clearly limits the insights that can be generated and conclusions that can be drawn. A notable exception is Zietsma and Lawrence's 
(2010) study of the British Columbia forestry field. By collecting extensive data across the field - from forestry companies, environmentalists, and government officials - these authors are able to paint a more evenhanded picture of each stage of the field's transformation. In particular, their multi-vocal data allow them to show how initial confrontation gave way to small-scale collaborations between the conflicted parties. Future institutional work research would benefit from more balanced accounts such as this one that take into consideration the perspectives of all the groups involved in conflict situations. This would allow researchers to provide more nuanced accounts of the dynamics of conflict as they unfold, and the of role institutional work in resolving them.

\section{Types of institutional work: How do actors influence institutions?}

The foundational book chapter by Lawrence and Suddaby (2006) divided institutional work according to its intended outcomes, i.e., into the work of creating, maintaining and disrupting institutions. In this chapter, we provide an alternative perspective by classifying institutional work based on the means that are used to achieve particular institutional objectives. This leads us to distinguish between three types of institutional work: first, symbolic work that uses symbols, including signs, identities and language, to influence institutions; second, material work that draws on the physical elements of the institutional environment, such as objects or places, to influence institutions; and third, relational work that is concerned with building interactions to advance institutional ends.

Symbols dominate institutional work. The popularity of symbolic work can be explained by institutional theory's strong roots in symbolic interactionism, particularly the influential work of Berger and Luckmann (1966). This long tradition has inspired many studies that show how actors can strategically interact with symbols to achieve their institutional objectives. Indeed, 
nearly all of the studies in our review discussed symbolic work to some extent, with 46 out of 53 placing particular emphasis on it. In these papers it is apparent that scholars have drawn on a wide range of symbols, including categories, identities, narratives, rhetoric, rules and scripts, among others (e.g., Leung et al., 2014; Raviola \& Norbäck, 2013; Singh \& Jayanti, 2013). While actors have a huge array of symbols available to them, deploying these symbols so that they resonate with key actors is far from straightforward - connecting to existing institutional arrangements, adapting broader themes, and neutralizing oppositional symbols have been identified as important skills in this regard (e.g., Riaz et al., 2011; Ruebottom, 2013; Trank \& Washington, 2009).

The role of narratives and identities feature especially strongly in the literature on symbolic forms of institutional work. Actors construct narratives through the "selection, combination, editing, and molding of events into a story form” (Zilber, 2009:208). These narratives can become powerful symbols that actors can use to explicate situations, justify actors, and defend different courses of actions. Closely related is the concept of rhetoric, which involves the use of "persuasive language" (Ruebottom, 2013:100). Studies have shown that actors employ narratives (and rhetoric) in different ways to pursue institutional work (e.g., Riaz et al., 2011; Zilber, 2007). One approach is for actors to draw on meta-narratives that exist across multiple fields and thus resonate with many salient audiences. For example, Zilber (2009) found in her study of a rape crisis center that actors translated and re-interpreted societal meta-narratives to justify feminist and therapeutic practices. This included using them to socialize new members by, for instance, embedding narratives into routines. As a result, the center was able to justify its activities with stories that resonated widely across society. A second approach involves the creation of new stories that invoke widely accepted tropes, vocabularies or rhetorical devices 
rather than specific societal meta-narratives. For example, Ruebottom (2013) shows that social entrepreneurs in Bangladesh were able to build legitimacy for their ventures by constructing narratives that depict themselves in the role of heroic protagonist standing up to the villainous antagonists.

Identity - a self-referential statement of "who we are" or "who I am" (Albert \& Whetten, 1985 ) - is the second main type of symbol institutional work that researchers have focused on. Specifically, scholars have explored how actors construct and reconstruct identities at different levels - both individual and organizational - to influence institutions. This research suggests that identities and institutions are in a constant interplay. As a result, actors can sometimes use their identities to influence broader institutions and, in turn, sometimes adapt their identities to fit these institutions (e.g., Creed et al., 2010; Goodrick \& Reay, 2010). The former case is highlighted by Jones and Massa's (2013) study of Frank Lloyd's Wright Unity Temple church building which moved from "entrepreneurial anomaly" to "consecrated exemplar". They show how actors had to publicly express and defend their novel architectural identity to attain legitimacy for their work. The latter case is highlighted by Gawer and Phillips' (2013) observation that Intel had to adapt its identity to introduce the platform logic across its industry. Specifically, it had to make new identity claims, and resolve tensions between its established identity and new platform practices. These studies highlight that institutional workers are often required to renegotiate their identities as they seek to shape the institutional landscape.

Despite a rich vein of existing research, symbolic work continues to offer much promise for students of institutional work. For example, Granqvist and Gustafsson (In press) extended institutional work to account for the temporal realm. Through a study of the creation of a new university blueprint in Finland, they find that the strategic manipulation of notions of time - for 
instance by creating urgency or enacting momentum - can have a powerful bearing on the outcomes of institutional projects. Two underexplored types of symbols that offer much promise are the visual and the sonic. Despite the old adage that a picture says more than a thousand words, it is unclear how institutional workers can effectively employ image-based symbols (see Meyer, Höllerer, Jancsary, \& Van Leeuwen, 2013, for an overview). Similarly, despite being constantly surrounded by them, scholars have been largely silent about the role of sounds in institutional dynamics (see Schwarz, 2015, for an exception). For example, chants are often instrumental for mobilization during political revolutions or anti-corporate protests. Research that explores the potency of the sonic realm for institutional action has the potential to make an important contribution.

The exploration of the tangible side of institutional life has also proven a less well trodden path. In particular, we know little about material work, which involves the manipulation of physical aspects of the institutional environment, and more specifically about the role of materiality in shaping institutional work. Indeed, only five studies in our review explored the material dimension in any detail. This, admittedly small, body of work has suggested three roles for the material realm. First, actors can draw on material objects to interpret situations that they face. In this instance, objects contain institutional information that can guide decision-making. For example, in their study of technological change in an Italian newspaper business, Raviola and Norbäck (2013) showed that actors can use the material functions of technology - in which institutions are inscribed - to navigate new situations. In their case, journalists used their experiences of working with paper-based version of newspapers to make sense of proposals for a digital version. Second, actors can use material objects to extend their agency by using them to perform institutional work. For example, in their study of the introduction of new prizes into the 
Italian public sector, Monteiro and Nicolini (2015) show that actors can use material objects for many types of institutional work, such as educating others, theorizing institutions, or reconfiguring normative networks. Third, material objects can complicate institutional work. For example, in their study of the role of place in Vancouver support programs for the hard-to-house, Lawrence and Dover (2015) show that the unique materiality of a daycare facility led to significant shifts in how actors approached their institutional work.

As these studies show, material work offers much promise for the study of institutional work. One possible route forward would be to engage with theoretical ideas and perspectives from elsewhere in the social sciences that place greater emphasis on the role of the material. For example, institutional work researchers might consider drawing on actor-network theory or theories of socio-materiality to help extend and refine their thinking (Latour, 2005; Orlikowski \& Scott, 2008).

Relational work is another important type of symbolic institutional work. The study of relational work explores how actors can influence institutions through their interactions with others. To date this has been studied in two different ways. In a first stream of research, scholars have explored how actors can gain followers for their cause. Studies have suggested that to this end actors can build networks, amplify each other's initiatives through indirect work, and suppress alternatives (Bertels et al., 2014; Boxenbaum \& Strandgaard Pedersen, 2009; Rojas, 2010b). For example, in a study of Bolivian microfinance, Dorado (2013) finds that actors can use group dynamics to recruit supporters: the presence of a group helps to motivate others to join it, inspires members to identify opportunities, and facilitates access to yet more potential members. Other studies have shown that actors may engage in relational institutional work in a variety of ways in order to entangle others in their institution - ranging from the subtle use of 
rituals to aggression and other forms of coercive behavior (Dacin et al., 2010; Martí \& Fernández, 2013).

In a second stream of research, scholars have explored how actors can engage in collaborations with others in their field. This work has focused in particular on role of factors such as status, social position, goal alignment, and role clarity in collaboration success (Bertels et al., 2014; Empson et al., 2013; Wright \& Zammuto, 2013; Singh \& Jayanti, 2013; Sminia, 2011). It has also considered the challenges of co-ordination and control (Clark \& Newell, 2013; Zietsma \& McKnight, 2009a). For example, Dorado (2005) suggested that large groups of loosely connected actors can influence institutions when these actors are "convened" to act in concert - a process by which big collectives work in a seemingly independent manner towards a common goal with minimal formal coordination.

It is notable, however, that existing research on relational institutional work has focused primarily on the work involved in influencing like-minded actors from the same field. We know much less about the work needed to marshal support from actors in different fields, who may have vastly different goals and occupy very different roles. In a notable exception, Wijen and Ansari (2007) draw on regime theory to explain how collective inaction was overcome to realize the Kyoto Protocol to limit emissions. They identify several drivers that enabled heterogeneous actors to reach a productive agreement. Another blindspot in current research is the work involved in negotiating formal institutional standards. One interesting exception is Helfen and Sydow's (2013) study of the negotiation of new labor framework agreements between global trade unions and multinational corporations. These authors show that relational work can yield vastly different outcomes and illustrate both the potential and pitfalls of "negotiation work" for institutional change. 
Taken together, the research on institutional work has in its maiden decade played an important moving forward our understanding of the relationship between agency and institutions. In particular, it has provided a new vocabulary and way of thinking about a range of institutional dynamics, and the purposive action required to influence them. But... there is still much to be done to fulfill the potential of this perspective. In the rest of this chapter, we address two sets of issues: the theoretical holes in the fabric of institutional work research that have been left by selective attention to some sets of dynamics while ignoring others; and the even larger gap between the theoretical contributions of the institutional work perspective and its impact outside the academy.

\section{Missing in Action: Logics, Networks and Objects}

In reviewing the existing literature on institutional work, we found it prioritized field- and organization-specific institutions rather than institutions that cut across fields. It also focused on actors who either act on their own or collaborate in relatively homogenous alliances but said much less about collaborations between diverse groups of actors. Moreover, symbolic forms of institutional work were dominant, with institutional work related to the material aspects of institutional life seldom considered. Next we explore the potential for research on institutional work to move beyond each of these tendencies.

\section{Institutional Work, Institutional Logics and "Big" Institutions}

The study of institutional work has primarily focused on the work of actors to affect field- or organization-specific institutions, but this tendency, we argue, is neither inevitable nor helpful. In this section, we consider how the institutional work perspective might be broadened to incorporate a concern with more expansive institutional configurations. We begin by exploring the existing and potential connection between the study of institutional work and the 
study of institutional logics. We then discuss some of the "big" institutions not addressed within an institutional logics perspective and how these might be brought into the study of institutional work.

There has emerged a curious, and we suggest artificial, schism over the past decade between the two most dynamic and vital areas of institutional research and writing: institutional work and institutional logics. Each of these concepts has generated a plethora of theory and empirical research, exploring the core of the ideas and elaborating their dynamics in a range of contexts, but there has been relatively little systematic effort to examine the relationship between the two. In an essay exploring this divide, Zilber argues that these two streams of work "each developed within a distinct tradition and with its own trajectory" but share an impetus to "bridge the tension between structure and agency that undergirds the development of neo-institutional theory for decades now" (Zilber, 2013: 89). She goes on to argue that the "tension" between these two streams represents "the most recent incarnation of a long series of theoretical conundrums within neo-institutionalism, each igniting deep and ongoing discussions that pushed the theory forward", including diffusion vs. translation, stability vs. change, structure vs. agency, and the heroic institutional entrepreneur vs. the cultural dope. Zilber suggests that this tension is a healthy one such that institutional research and writing might best be served by keeping the streams separate, appreciating what they each bring to our understanding of organizations and institutions, and recognizing their limitations.

Although we appreciate Zilber's arguments, we believe there may be significant insight gained by integrating the concept of institutional logics more deeply into the study of institutional work. More specifically, we argue that the concept of logics could provide a way into understanding how actors work to shape large-scale, cross-field institutions. In their pivotal 
essay, Friedland and Alford (1991) argued that in contemporary Western societies there exist five major institutions each with an associated institutional order, which Thornton et al. (2012) built on to articulate a set of seven institutional orders: family, community, religion, state, market, profession, corporation. Shaping the meaning of these major institutions represents a form of institutional work largely unexamined in the literature on institutional work, and the literature focused on institutional logics reveals the same gap - both literatures tend to ignore how actors purposefully and skillfully affect the meaning and status of major institutions. Instead, the study of institutional logics has focused primarily on the movement of these logics into new domains (Reay \& Hinings, 2009; Thornton, 2002), and the ways in which competition among logics plays out in fields (Lounsbury, 2007) and organizations (McPherson \& Sauder, 2013; Pache \& Santos, 2013). Even in their exhaustive articulation of an institutional logics perspective, Thornton et al. (2012) pay little attention to the potential for actors to engage in work aimed at shaping major societal institutions.

This gap is unnecessary and unhelpful. Examining how actors work to shape the meaning and status of institutional orders could provide the basis for a productive and interesting, though challenging, extended research program. Important to such an investigation would be shifts in the kinds of actors on which we usually focus in institutional work research, and the kinds of strategies and tools in play. If we take, for instance, the institutional order of the corporation, we might look historically or recently at the efforts of actors to shape the meaning and status of this institutional order, rather than any particular instantiation of it. We might also look at how the corporation takes markedly varied forms around the world and the institutional work that has helped to sustain such divergence. These differences become apparent not only by comparing the corporate form in the West with its counterparts in emerging economic giants like China and 
India, but by considering the stark disparities between corporations within the West itself (see Dore, 2000). The concept of a corporation, its meaning and its role in society have been the objects of sustained institutional work in the West since at least the $18^{\text {th }}$ century, when they began to be constructed as private economic entities, rather than state-chartered entities. Over the $20^{\text {th }}$ and $21^{\text {st }}$ centuries, the definition of a corporation and its relationship to the societies in which it operates have continued to be objects of institutional work, focusing on a range of dimensions including criminal culpability, civil liability and social responsibility. Despite the enactment of a broad range of institutional work that has shaped the corporation as a fundamental institutional pillar of societies globally, relatively little institutional research has examined this work.

As a second example, take the family. This institutional order has been a battleground for complex, conflictual institutional work for centuries. Even looking back at only the last few decades, we see institutional work by individuals, organizations, networks, states and branches of government all attempting to shape societal definitions of what constitutes a family, its sources of authority and legitimacy, mechanisms of control, and its relationship to the economy. In the US, recent institutional work has resulted in highly pitched political and cultural contests referred to as the "family wars" (Stacey, 1993: 545). At the heart of these "wars" is the argument that "The family, far more than government or schools, is the institution we draw the most meaning from. From the day we are born, it gives us our identity, our language and our expectations about how the world should work" (Goldberg, 2015). What "the family" is, though, and how it relates to other institutional orders in society, are significantly contested, with contestants including politicians, policy makers, religious leaders, media figures and social scientists. Looking just at the institutional work of social scientists in this war, we see at least two distinct roles. One 
traditional role of social scientists in the debates over what constitutes a proper and effective family has been to contribute and interpret scientific "facts" - the results of empirical studies that tend to focus on the relationship between family structure and a particular outcome, such as the educational achievement of children, or the economic success of family members (Biblarz \& Gottainer, 2000; Biblarz \& Raftery, 1999). A second role has been to focus on the concept of "family" itself, as illustrated by Judith Stacy (1993:545), a University of California sociologist, who argues that: "no positivist definition of the family, however revisionist, is viable", because it is "an ideological, symbolic construct that has a history and a politics". The work of academics to define the concept of a family is important for our discussion because it so clearly illustrates the potential for even individual actors to shape the nature of institutional logics.

Although we have drawn on the concept of institutional logics as a response to the lack of attention in the study of institutional work to "big" institutions - institutionalized practices, beliefs and norms that cut across fields and seem to endure over long periods of time - this perspective draws our attention to only a particular set of institutions. This appears to ignore other major institutions, some of which seem even more basic and enduring than the logics articulated in the various formulations. The institutions of race and gender, for instance, are undeniably central to people's lives, communities, cultures and political economies, but somehow sit outside of the institutional logics identified by Friedland and Alford (1991) or Thornton, Lounsbury and Ocasio (2012). For the study of institutional work, understanding how actors work to shape definitions of race and gender, their place in societies, and their relationship to organizational life represents a profoundly important direction for future research. Though not explicitly focused on institutional work, the chapters in this volume by Rojas and by Dobbin and Kalev provide important contributions, helping us move in this direction. These institutions 
matter in their own right not least because they are fundamental to understanding processes of marginalization and discrimination - why some groups are excluded from opportunities while others have privileged access to them. More fundamentally, all institutions are both gendered and racialized (Hawkesworth, 2003). This includes the 'big' logics discussed above (for example, it is surely impossible to study the institutional dynamics of the family without considering gender roles, and mixed race marriage remains taboo in many parts of the world), but also meso-level institutions such as development, social enterprise, and the professions.

\section{Institutional Work by Networks of Heterogeneous Actors}

A second significant gap in the study of institutional work concerns the actors that have been studied - our review shows a tendency to focus either on individual actors or on relatively similar sets actors working together. Indeed, it is striking that institutional work has very little to say about collaborations between heterogeneous actors who hail from different fields or who hold radically different world-views; only a handful of studies in our review explored such situations. Where heterogeneous actors are considered, it tends to be in the context of conflict and division - with the relevant actors competing over the institutionalization of rules, norms, practices and boundaries. Although these situations are certainly common, they ignore the important possibility of cooperation among diverse sets of actors.

Two institutional work studies covered in our review do offer significant insights into heterogeneous collaboration and are worth highlighting. First, Wijen and Ansari (2007) draw on regime theory in their analysis of the emergence of the Kyoto Protocol to suggest that the creation of common ground is imperative for disparate actors to join forces. While common ground is usually not a major concern among homogeneous actors who share fields, worldviews and objectives, the lack of common ground can be a major impediment to heterogeneous 
collaborations that cut across fields. Second, Zietsma and Lawrence (2010) suggest an alternative approach for building collaboration between heterogeneous actors: the creation of safe spaces for small-scale experimentation, in which seemingly oppositional actors can cautiously learn to collaborate. These studies notwithstanding, the lack of attention to collaborations between heterogeneous actors leaves many important questions unexplored. Much research remains to be done to explain how such difficult, yet important, collaborations can influence institutions. For example, we lack answers to very practical questions that institutional work research could inform, such as: how can NGOs partner with governments to improve global health? And how can charities collaborate with multinationals to change long-held notions of gender? To tackle this shortcoming, institutional work scholars can learn much from other domains that have explored how heterogeneous actors can work together.

Research on cross-sector partnerships provides a useful starting point, given its focus on explaining alliances between heterogeneous actors that tackle complex social issues (Selsky \& Parker, 2005). This work has shown that goal conflict is perhaps the core tension that lies at the heart of most cross-sector partnerships: the involved actors likely have vastly different objectives, as well as time horizons, resources and capabilities (Huxham \& Vangen, 1996). For example, while government actors may be concerned with improving the efficiency of the provision of public services, non-profit organizations may be focused on achieving social and environmental goals, and at the core of corporate forms is, ultimately, a concern with how partnerships feed into overarching commercial objectives such as profits and market share (Seitanidi, Koufopoulos, \& Palmer, 2010; Selsky \& Parker, 2005). The precise nature of these tensions are likely to differ depending on the type of partnership in question - public-private, public-nonprofit, private-non-profit, or trisector (Selsky \& Parker, 2005). 
Regardless of the type of partnership, scholars have suggested a number of practices that can support effective collaboration across sectors and which may be of particular interest to institutional work scholars. Perhaps the most important practice - or type of institutional work is the creation of "meta-goals" that apply to the entire partnership and are designed to override, or at least place in perspective, the goals of the individual partners (Huxham \& Vangen, 1996). The construction of shared goals can be painful for the parties involved, and include "recurring episodes of problematic negotiation activity" (Ackermann, Franco, Gallupe, \& Parent, 2005:312). Eden and Huxham (2001) describe in detail the social processes underpinning "the negotiation of purpose" in the context of different partnership dynamics and the trauma that can be experienced when these negotiations do not follow a smooth path. Soundararajan and Brammer (2015) begin to reveal some of these dynamics from an institutional work perspective. Their analysis of global production networks in garment manufacturing reveal how suppliers must negotiate a complex web of relationships with governmental organizations, nongovernmental organizations, and other companies in the supply chain as part of efforts to ensure ethical labour practices. The authors further reveal a distinct set of strategies that suppliers engage in to manage the complexities of these relationships, ranging from "intentional deception" to "consensual cooperation".

A second key practice, or type of institutional work, that has been identified in the crosssector partnership literature as underpinning effective collaboration is the construction of a coherent partnership identity (Hardy, Lawrence, \& Grant, 2005). Koschmann, Kuh and Pfarrer (2012) argue that cross-sector partnerships "must continually manage individual and collective interests alongside efforts to create novel solutions to complex social issues" (p. 340-341). They further suggest that "It is the managing - not resolving - of these tensions that increases the 
value potential" of such partnerships (p. 341). This requires partners to engage in complex identity work - while a coherent partnership identity can increase meaningful participation with stakeholders and help manage tensions, such an identity also needs to be flexible. The reason is that partnership effectiveness "hinges on members' capacity to avoid inserting their own assumptions regarding others, asserting their sectional interests, and believing that their backgrounds provide special insight into the 'correct' answers to partnerships' objectives" (p. 341). Given the increasing importance of identity work as a type of institutional work (Creed et al., 2010) these dynamics are potentially of much interest to institutional theorists.

Interestingly, and more broadly, an important outcome of cross-sector partnerships is not only their "direct impact" - the immediate, practical outcomes of the partnership - but also their "indirect impact" - their influence on the values, beliefs and practices within a given problem domain (Selsky \& Parker, 2005). This emerging focus on "indirect impact" resonates with the ambition that we have set out for institutional work scholars to explore how actors can influence the truly "big" institutions. More broadly, cross-fertilization between scholars of institutional work and cross-sector partnerships would be fruitful, given the complementary expertise of the two fields. From the point of view of our arguments in this chapter, research on cross-sector partnerships offer institutional work scholars a detailed understanding of how heterogeneous alliances can emerge and the nature of the unique challenges between different types of partnerships - two essential areas about which institutional work has been notably silent (Koschmann et al., 2012; Selsky \& Parker, 2005).

\section{Institutional Work Involving Material Objects}

The last major gap we identify in the literature on institutional work is the role of material objects in motivating and shaping institutional work. The significance of this gap has been made 
clear in recent years by the burgeoning literature on materiality in organization studies and sociology. Despite this growth in interest, research connecting material objects and institutional work is still relatively scarce, reflecting a more general problem in organizational institutionalism (see Chapter by Jones, Meyer, Jancsary \& Höllerer in this volume).

One of the first detailed discussions of the relationship between materiality and institutions was Pinch's (2008) essay rooted in the social studies of science and social construction of technology literatures. Pinch (2008: 461) argues that the "traditional sociological approach carves up the world" into separate social and material domains, with sociologists dealing only with social things, leaving the "world of objects, machines, and materials ... left unanalyzed or considered the territory of others". Central to Pinch's argument is the mutual constitution of the material and the social, which he suggests is nodded to in sociological reasoning but not taken seriously or examined in detail with respect to how such mutual constitution might occur or with what consequences.

A basis for integrating materiality into institutional analysis might be the sociology of technology that emerged in the 1980s (Bijker, Hughes, \& Pinch, 2012; Latour, 1987; Latour \& Woolgar, 1986). From this perspective, unpacking the mutual constitution of the social and material involves research that can "uncover and analyze the choices embedded within technologies and technological regimes and show how these choices are tied to wider societal concerns" (Pinch, 2008: 469). A key strategy in this tradition is to focus on specific technologies, examining their histories and particularly the interplay of the engineering practices and decisions involved in their creation and the societal interests that were embedded in those practices and decisions. From the institutional literature, a fascinating example is Munir and Phillips' (2005) study of the "birth of the "Kodak Moment", that involved the introduction of the roll-film camera 
and the transformation of photography from a specialist practice into an everyday activity. Munir and Phillips argue that Kodak acted both as a technological innovator and an institutional entrepreneur and that these roles were tied tightly to each other. In 1882, Kodak introduced the roll-film camera, which made photography much more convenient, but came with a significant loss of image quality unacceptable to the professional photographers. Kodak's eventual success with this design depended on four discursive strategies through which they re-shaped the institution of photography, including tying photography to the institutionalized notion of a holiday, and creating new roles, such as "the Kodak girl" who carried a camera in her handbag. Munir and Phillip's (2005) analysis of these changes in photography powerfully illustrate the ways in which materiality, meaning and society are interpenetrated, and - importantly for our discussion - how that nexus is the object of significant work on the part of interested actors. In the institutional work literature, the role of the material has only begun to be examined in a systematic manner. Raviola and Norbäck's (2013) study of an Italian business newspaper that integrated its online and offline news offerings represents an important step in this direction. Raviola and Norbäck focus on the agencement (Callon, 2008) - "arrangements of humans and non-humans, which have the capacity to act" - that operate in the news room, which in this case is constituted by the journalists, the website and the newspaper. In exploring the role of these socio-technical arrangements in institutional work, they argue that, "The new technology (website) offers possibilities for action - indeed proposes action - to the journalists that differ from the action the print proposes and the journalists engage in on the newspaper" (Raviola \& Norbäck, 2013: 1178-1179). This idea of the website proposing possible actions is core to their analysis of how material objects become included in the institutional work of human actors. They show through three different episodes how the website proposes action that then requires 
deliberation and institutional work on the part of the journalists, and how the old technology (the newspaper) inserts itself into the process as a resource for that institutional work. Raviola and Norbäck (2013) thus present an image of materiality in institutional work in which technology plays an active part - triggering institutional work by proposing actions that cause dilemmas, constructing how these dilemmas are interpreted by framing understandings of the present and the past, and shaping action to resolve such dilemmas. We have highlighted in this section that scholarship would benefit from a detailed investigation into the work involved in changing big institutions, collaborating with networks of heterogeneous actors, and employing objects. While institutional work research has somewhat neglected these important topics, cross-fertilization with other fields has much to offer. We suggest that institutional work scholars can particularly connect to research on institutional logics, cross-sector partnerships and materiality in order to illuminate these relative blind spots.

\section{Making Research on Institutional Work Matter}

One of the most common complaints among institutional scholars is the lack of impact their research has on the world outside of universities. Management practice and government policy are heavily influenced by academic research, but this research is typically rooted in disciplines directly connected to the issue at hand, such as epidemiology in healthcare (e.g., Upshur, VanDenKerkhof, \& Goel, 2001), criminology in law enforcement and corrections (e.g., Mastrofski \& Parks, 1990), and education research in schooling (e.g., Lee \& Barro, 2001). And then there is the trans-disciplinary influence of economics; more than any other discipline, research on economics has infiltrated and profoundly influenced nearly every facet of management practice and government policy(Franklin, 2016). 
The debate about organization's theory's (lack of) relevance to the issues and challenges facing managers, policy makers, and society more broadly, has ebbed and flowed for many years. Hinings and Greenwood (2002), for instance, note that organization theory has the potential to offer distinctive insights about contemporary society, the nature of the problems it faces, and the varied effects of organizational action on these problems. But they conclude that organizational research has consistently failed to address such "grand themes" or to take seriously its role as a "policy science" (Hinings \& Greenwood, 2002: 419-420). Unfortunately, this critique applies to institutional theory at least as much as to other areas of organizational research. This is disappointing because institutional theory comprises, in our view, a sophisticated set of theoretical tools and an associated vocabulary that endows it with significant potential to contribute to our understanding of the grand themes and challenges to which Hinings and Greenwood refer. This point is reinforced by Munir (2011: 115) who argues that although the 2008 financial crisis represents a "treasure chest" for institutional theorists, offering the chance to engage with one of the most significant global events in recent decades, we have shown relatively little interest in studying this tumultuous period and learning from it.

Within the domain of organizational institutionalism, the study of institutional work is particularly well placed to tackle pressing real-world challenges. By exploring the highly practical question of how actors can shape institutions it is uniquely positioned to not only provide academic answers for the ivory towers but to create tangible change in practice. At the same time, and as implied by our discussion in the previous section, the questions that institutional work scholars typically address, how the analysis of institutional work is connected to empirical worlds, and the conclusions that institutional work research typically provides 
would all need to shift significantly in order for institutional work research to realize its practical potential.

\section{Where to start: Institutions that matter}

To create a body of institutional work research with greater social impact, one way forward is to begin to address institutions and institutional work of greater consequence - those that have the most profound effects related to global social challenges. According to the United Nations, the international community must grapple with no fewer than 30 fundamental global issues, including global health, gender inequality, the continent of Africa, access to potable water, peace and security, and refugees and migration. ${ }^{1}$ For the sake of illustration, we consider one issue that has been a key concern of the United Nations: slum dwelling in the global south. More than one billion people live in slums, around 14 per cent of the world's population. More than 100,000 people move from rural areas to urban slums every day. The high cost of medicines in the global south, acute shortages of potable water, and poor nutrition mean non-communicable diseases that are mostly treatable and/or preventable kill millions of slum dwellers every year. From our perspective, these slums and their consequences represent not only a global challenge, but a nexus of institutionalized practices, beliefs, values and assumptions tied to complex combinations of institutional work, as are the potential remedies for the harms they currently effect. These dynamics offer opportunities to build novel theoretical insights and, perhaps more importantly, to shed light on deep-rooted, intractable global problems that shape the lives of many millions of people. Such a focus would begin to render obsolete any questions about institutional theory's relevance to "real world" issues and problems (Nicolai \& Seidl, 2010).

\footnotetext{
${ }^{1}$ http://www.un.org/en/globalissues/ [Accessed 31/05/16]
} 
Following the pattern set in the earlier sections of this chapter, we turn from "what" to "who". Investigating the institutional work connected to slums in the global south would, we suspect, involve two complex sets of actors. The first set of actors concerns those whose institutional work maintains the institutions that underpin slums. This is, of course, a potentially challenging group to study. It is unlikely that anyone is going to readily admit to engaging in institutional work that maintains the wide array of harms inflicted on people due to living in slums. At the same time, this is a critically important set of actors to identify; one of the most important insights that has emerged from the study of institutional work over the past decade is that complex institutions do not simply endure, but require significant maintenance efforts in the face of potential disruption and entropy. The second set of actors concerns those engaged in efforts to disrupt the institutions associated with slums, and create new institutions that might provide people living in slums with better access to key resources, routes out of slum living, and perhaps alternative forms of community that could replace slums. Identifying and investigating the institutional work of this second set of actors would be associated with its own challenges, as it is likely to involve diverse, complex networks of actors spanning sectors and countries, and include kinds of actors, such as governments, less familiar to many institutional work scholars.

Finally, we ask whether studying institutions that matter might lead us to consider differently the question of "how" institutional work is accomplished in these contexts. Clearly, the study of institutional work will lead to continued identification of distinct forms of work as it explores new empirical contexts, regardless of whether those contexts feature 'big' or 'small' institutions. We believe, though, that while much current research focuses on symbolic or relational or material work, research on major social issues is likely involve complex combinations of all three. Consider again our slum dwelling example. One of the key problems 
that blights the lives of slum dwellers is open defecation. In response, NGOs have invested billions of dollars in the construction of toilets (material work), a complex task given that many slums are built illegally on land not owned by the residents. Yet even where they have been built, toilets often remain largely unused. This is partly because using a toilet is an institutionalized practice that is learned through socialization into culturally specific meaning systems that construct a relationship between sanitation and wellbeing. In many cases, NGOs have responded to this problem by engaging community workers to deploy narratives that make the link between sanitation and personal and community health (symbolic work). Moreover, as noted above, addressing the problem of sanitation in isolation will have a relatively marginal impact on the lives of slum dwellers. Thus, organizations dealing with this problem need to ally with other actors working on, for example, nutrition, potable water, and healthcare (relational work). Each issue poses formidable challenges in its own right but is also intimately connected and interwoven with other, broader issues. This renders the task of studying and changing the institutions that matter particularly difficult - and very important.

\section{What it might look like: Applied institutional work as a policy science}

Focusing on institutions and institutional work of global significance only begins to answer how we might make institutional work research matter; still in question is what our own research activity would look like, and how we would convert our interest and attention into impact. Earlier, we lamented the limited engagement by institutional researchers in large-scale social problems and issues. Interestingly, there have emerged conversations among organizational scholars that point to the potential for such engagement in domains as diverse as democracy (Barley, 1990; Zald \& Lounsbury, 2010), financial crises (Lounsbury \& Hirsch, 2010; Munir, 2011), and climate change (Hoffman \& Jennings, 2015; Knox-Hayes \& Levy, 
2011). What these authors suggest, however, is an analytical engagement - a role for institutional scholars in explaining these grand institutional challenges - rather than an activist engagement. With a few exceptions (Davis, 2015; Zuckerman, 2010), even when institutional scholars have engaged with grand institutional challenges, we have tended to remain at our desks, not leaving our offices to apply our tools and insights to change the world.

We propose an alternative: an active, engaged, political program of applied institutional work research, the aim of which is not only to understand grand social challenges but to affect them and in so doing change the world. In particular, we suggest that sets of institutional scholars establish organized mechanisms through which they can intentionally and programmatically work on affecting the world's grand challenges. We noted Hinings and Greenwood's (2002: 420) argument that organizational research has failed as a "policy science". It is this exact failure that could provide the space and motivation for scholars to develop applied institutional work research as a policy-focused arena of discourse and action.

What we are not suggesting is that applied institutional work emulate the dominant applied social science - economics - in its research methods, political methods or epistemology. It has been suggested that the certainty with which economics research articulates its findings and prescriptions is key to its attractiveness in policy circles - easy to follow, clear, and simple prescriptions when compared with the often "self-indulgent" and jargon laden findings associated with institutional research, and organizational research more broadly (Starbuck, 2003; Walsh, Meyer, \& Schoonhoven, 2006). Similarly, economic theory, and especially the neoliberal variants that have dominated transnational policy organizations, is appealing to political and corporate elites in the most affluent countries because it reinforces the wisdom of the markets that are currently rewarding and maintaining those same elites. Where neo-liberal 
economic policy has failed, however - and those spaces are vast and growing - there exists fertile ground for an alternative policy science and an alternative scientific politics. A program of policy-focused applied institutional work research could bring to those spaces a powerful and energizing approach to the integration of research and public policy. Rather than simple prescriptions that are decontextualized and ahistorical, applied institutional work research could provide culturally, socially and historically situated policy prescriptions. And rather than echoing the assumptions and anxieties of elites, applied institutional work could provide a medium for a complex chorus of voices that would cut across social, demographic and economic divides.

\section{Another Possibility: Institutional Work as Participatory Action Research}

Although imagining institutional work research as a policy science creates exciting possibilities, another, more hand-on approach is suggested by Dover and Lawrence (2010) in their essay on applied institutional work as a foundation for participatory action research. This form of action research revolves around the co-construction of practical knowledge by researchers and community members together in cycles of research, action and reflection (Greenwood, Whyte, \& Harkavy, 1993; Kemmis \& McTaggart, 2005). Although, there has been almost no conversation connecting institutional work and participatory action research, important points of potential connection exist. First, both emphasize the role of agency in understanding the dynamics of social systems, especially how, when and why significant social change occurs. Both approaches adopt a view of actors as "intelligent, creative, and purposive" (Dover \& Lawrence, 2010: 308). Participatory action research, however, suggests a significant shift in the epistemology of action, replacing a view of actors and action as objects of research, to one in which the relationship between researcher and researched is a subject-subject relationship (FalsBorda, 1991). Participants in this form of research are engaged with as competent and capable 
partners who participate in exploring their social worlds and realizing change (McIntyre, 2008).

Participatory action research suggests a more intimate and equal relationship than is usually adopted in institutional research, with participants involved in every step of the process identifying the research question, collecting and making sense of data, developing interventions or responses to the findings, and coming back to the theory that guided the research in order to reflect on what the findings might suggest for those ideas.

In practical terms, institutional scholars could either draw on participatory action research as a method or as an orienting perspective that forms part of their broader research philosophy. To draw on participatory action research as a method would involve using its many creative modes of engagement such as storytelling, photography, poetry, drawing, sculpture, drama and popular theatre (e.g., Ospina, Dodge, Foldy, \& Hofmann-Pinilla, 2008). Such approaches might provide a powerful basis for applied institutional work research: they could facilitate engaging with the embeddedness of individuals and groups in their institutional context, facilitating their awareness of institutions as well as a belief in their ability to affect those institutions. This first approach would thus likely open up much deeper and more varied insights into the institutions inhabited by the people we study. The second approach of engaging with the philosophy of participatory action research might provide an even more powerful foundation for applied institutional work, allowing us to bring our theoretical tools and empirical wisdom with us into the field, but then work in collaboration with members to identify our research questions, establish our goals in terms of impact and knowledge generation, and develop ways of knowing that ensure the validity of our findings is consistent with the working epistemologies of researchers and members. 


\section{Tackling Grand Challenges: A New Type of Scholarship?}

In sum, thinking about grand challenges - such as slum dwelling in the global south from an institutional work perspective is both fascinating and intimidating. The complexity of the issues involved poses profound challenges with respect to research design, data collection and analysis, skills and networks needed, and links to academic careers. Moreover, there will be important limits to what can be uncovered in individual studies, and so institutional work scholars may need to think differently about how research is funded and organized. The study of grand social challenges from multiple perspectives may also require large teams of researchers working as part of an overarching initiative rather than small groups working independently.

\section{The Past, Present and Future of Institutional Work Research}

The first decade of institutional work research has been an exciting journey. Our image of institutions has shifted, with an increasing recognition that although institutions are powerful forces in society, they are also subject to the agency of individuals and collective actors who create, shape and disrupt them. Our conceptions of institutional agency have broadened considerably, with research documenting the complex range of long-term and day-to-day strategies through which actors craft and cope with institutional arrangements. As much as institutional work research has progressed, however, important blind spots remain. We now know a great deal about how actors shape field- and organization-level institutions, but relatively little about the institutional work associated with truly "big" institutions that span society and wield disproportionate influence over us all. We have a growing understanding of the inhabited worlds of individuals and collective actors that engage in institutional work, but a much less developed appreciation of when, why and how networks of heterogeneous actors work together to shape institutions. Our research has described and analyzed symbolic forms of institutional 
work in detail, while we still know much less about relational and material work. Taken together, institutional work research is on its way towards its own adolescence but is experiencing growing pains as vital parts lag behind.

We have pointed to three sets of ideas with tremendous potential for integration into the study of institutional work: the institutional logics perspective, research on cross-sector partnerships, and scholarship on the role of materiality in organization studies and sociology. More broadly, we have proposed an agenda for institutional work research that expands its aims to include contributing to efforts to address the world's grand challenges by shaping policy and practice.

The image we have in mind for applied institutional work research is inspired by the pioneering careers of Paulo Freire and Myles Horton. Freire was an educator whose ideas were rooted in his work with Brazil's “illiterate poor” (Torres, 2014). These early experiences provided the foundation for his most influential book - the Pedagogy of the Oppressed (Freire, 2000) - which focused on the relationship between knowledge and social class, and had a profound influence on the study and practice of teaching throughout the world. Freire advocated a relationship between learners and educators based on a view of knowledge as mutually cocreated. Similar in many ways, Myles Horton's ideas were inspired by his involvement in the US civil rights movement, and led to his co-founding of the Highlander Folk School which was based on an appreciation of situated knowledge and fought against segregation within the American schooling system.

While the thinking of Freire and Horton was rooted in practice, their work also addressed fundamental theoretical issues including whether education can ever be ideologically neutral, the role of authority in education, the role of charismatic leadership in teaching, and the similarities 
and differences between 'educating' and 'organizing' (Bell, Gaventa, \& Peters, 1990). While Horton and Freire are in one sense 'extreme' examples - both were what now would probably be termed social innovators and both clashed with the authorities (Freire spent time in prison for his views, Horton was stigmatized as a communist during the McCarthy era and forced to close the school he co-founded) - they capture our imagination and offer a glimpse of what might be possible as institutional researchers if we first engage with significant institutions and social issues, and then immerse ourselves in empirical settings that we not only try to study but also work to change for the better.

Whether the agenda that we advocate can be realized in a business school world that increasingly embraces narrow metrics based on publication in a small number of elite journals is not clear. The need for management researchers to "bridge the relevance gap" (Starkey \& Madan, 2001) has been much discussed over several decades, but little progress has been made. A quick glance at the major management journals reveals only a small subset of papers that speak to significant organizational and societal issues. The anodyne nature of the so-called "rigor versus relevance" debate has hardly helped matters.

Despite these profound and longstanding challenges, there are small signs of hope and some grounds for optimism. In the UK, 'impact' (an admittedly vague concept) is now explicitly considered when measuring the research performance of university departments, including business schools. Crucially, here 'impact' is not understood by how our research fares in journal rankings and citation counts within academia, but instead by how our studies create benefits for the world beyond academia, such as by improving society, the environment, or quality of life. Similarly, the Academy of Management Journal has actively encouraged the submission of manuscripts focused on issues and parts of the world that have been almost completely ignored 
by mainstream management research, including the "grand challenges" of our time. And for a new generation of younger scholars there is a growing dissatisfaction with the status quo and a strong desire to promote a different type of scholarship - one that resonates more closely with the ideas discussed above.

For scholars who share the desire to employ their research to contribute to the world, we think that the theoretical apparatus provided by the concept of institutional work offers a possible way forward. The concept is rooted in practice and has a strong focus on purposive action, but at the same time it is part of an institutional perspective that seeks to understand how systems of language and meaning perpetuate social structures that work in favor of some groups and against others. We hope that organizational researchers will build on our ideas to make organizational research in general, and institutional research in particular, more engaged with issues such as poverty, inequality and the environment, and less focused on the notion of 'theoretical contribution' for its own sake. 


\section{References}

Ackermann, F., Franco, L. A., Gallupe, B., \& Parent, M. 2005. GSS for Multi-Organizational Collaboration: Reflections on Process and Content. Group Decision and Negotiation, 14(4): 307-331.

Åkerström, M. 2002. Slaps, Punches, Pinches_-But not Violence: Boundary-Work in Nursing Homes for the Elderly. Symbolic Interaction, 25(4): 515-536.

Albert, S., \& Whetten, D. A. 1985. Organizational identity. In L. L. Cummings \& B. M. Staw (Eds.), Research in organizational behavior, vol. 7: 263-295. Greenwich, CT: JAI Press.

Barley, S. R. 1990. The alignment of technology and structure through roles and networks. Administrative Science Quarterly, 35: 61-103.

Battilana, J., \& D’Aunno, T. A. 2009. Institutional work and the paradox of embedded agency. In T. B. Lawrence, R. Suddaby, \& B. Leca (Eds.), Institutional work: Actors and agency in institutional studies of organizations: $31-58$. Cambridge, UK: University of Cambridge Press.

Battilana, J., Leca, B., \& Boxenbaum, E. 2009. How Actors Change Institutions: Towards a Theory of Institutional Entrepreneurship. The Academy of Management Annals, 3(1): $65-107$.

Bell, B., Gaventa, J., \& Peters, J. 1990. We make the road by walking: Conversations on education and social change: Myles Horton and Paulo Freire. Philadelphia: Temple University Press.

Berger, P., \& Luckmann, T. 1966. The social construction of knowledge: A treatise in the sociology of knowledge. Open Road Media: Soho, NY, USA. 
Bertels, S., Hoffman, A. J., \& DeJordy, R. 2014. The varied work of challenger movements: Identifying challenger roles in the US environmental movement. Organization Studies, 35(8): 1171-1210.

Biblarz, T. J., \& Gottainer, G. 2000. Family structure and children's success: A comparison of widowed and divorced single-mother families. Journal of Marriage and Family, 62(2): $533-548$.

Biblarz, T. J., \& Raftery, A. E. 1999. Family structure, educational attainment, and socioeconomic success: Rethinking the "pathology of matriarchy." American Journal of Sociology, 105(2): 321-365.

Bijker, W. E., Hughes, T. P., \& Pinch, T. J. (Eds.). 2012. The social construction of technological systems: New directions in the sociology and history of technology (Anniversary). MIT Press.

Bjerregaard, T., \& Jonasson, C. 2014. Managing Unstable Institutional Contradictions: The Work of Becoming. Organization Studies, 35(10): 1507-1536.

Bourdieu, P. 1998. Practical reason: On the theory of action. Cambridge: Polity Press.

Boxenbaum, E., \& Strandgaard Pedersen, J. 2009. Scandinavian institutionalism: A case of institutional work. In T. B. Lawrence, R. Suddaby, \& B. Leca (Eds.), Institutional work: Actors and agency in institutional studies of organization: 178-204. Cambridge, UK: University of Cambridge Press.

Callon, M. 2008. Economic markets and the rise of interactive agencements: From prosthetic agencies to habilitated agencies. In T. J. Pinch \& R. Swedberg (Eds.), Living in a material world: Economic sociology meets science and technology studies: 29-56. Cambridge, MA: MIT Press. 
Child, J., \& McGrath, R. G. 2001. Organizations Unfettered: Organizational Form in an Information-Intensive Economy. Academy of Management Journal, 44(6): 1135-1148.

Clark, C. E., \& Newell, S. 2013. Institutional Work and Complicit Decoupling across the U.S. Capital Markets: The Work of Rating Agencies. Business Ethics Quarterly, 23(1): 7-36.

Creed, W. E. D., Dejordy, R., \& Lok, J. 2010. Being the change: Resolving institutional contradiction through identity work. Academy of Management Journal, 53(6): 13361364.

Creed, W. E. D., Hudson, B. A., Okhuysen, G. A., \& Smith-Crowe, K. 2014. Swimming in a Sea of Shame: Incorporating Emotion into Explanations of Institutional Reproduction and Change. Academy of Management Review, 39(3): 275-301.

Currie, G., Lockett, A., Finn, R., Martin, G., \& Waring, J. 2012. Institutional work to maintain professional power: Recreating the model of medical professionalism. Organization Studies, 33(7): 937-962.

Dacin, M. T., Munir, K., \& Tracey, P. 2010. Formal dining at Cambridge colleges: Linking ritual performance and institutional maintenance. Academy of Management Journal, 53(6): $1393-1418$.

Daudigeos, T. 2013. In their profession's service: How staff professionals exert influence in their organization. Journal of Management Studies, 50(5): 722-749.

David, R. J., Sine, W. D., \& Haveman, H. A. 2013. Seizing Opportunity in Emerging Fields: How Institutional Entrepreneurs Legitimated the Professional Form of Management Consulting. Organization Science, 24(2): 356-377.

Davis, G. F. 2015. Editorial Essay What Is Organizational Research For? Administrative Science Quarterly, 60(2): 179-188. 
Davis, G. F., Diekmann, K. A., \& Tinsley, C. H. 1994. The Decline and Fall of the Conglomerate Firm in the 1980s: The Deinstitutionalization of an Organizational Form. American Sociological Review, 59(4): 547-570.

De Certeau, M. 1984. The practice of everyday life. Berkeley: University of California Press. DiMaggio, P. J. 1988. Interest and agency in institutional theory. In L. G. Zucker (Ed.), Institutional patterns and organizations: Culture and environment: 3-21. Cambridge, MA: Ballinger.

DiMaggio, P. J. 1991. Constructing an organizational field as a professional project: U.S. art museums, 1920-1940. In W. W. Powell \& P. J. DiMaggio (Eds.), The new institutionalism in organizational analysis: 267-92. Chicago: University Of Chicago Press.

DiMaggio, P. J., \& Powell, W. W. 1983. The Iron Cage Revisited: Institutional Isomorphism and Collective Rationality in Organizational Fields. American Sociological Review, 48(2): $147-160$.

Dorado, S. 2005. Institutional entrepreneurship, partaking, and convening. Organization Studies, 26(3): 385-414.

Dorado, S. 2013. Small groups as context for institutional entrepreneurship: An exploration of the emergence of commercial microfinance in Bolivia. Organization Studies, 34(4): 533557.

Dore, R. P. 2000. Stock market capitalism: Welfare capitalism: Japan and Germany versus the Anglo-Saxons. Oxford University Press on Demand. 
Dover, G., \& Lawrence, T. B. 2010. A gap year for institutional theory: Integrating the study of institutional work and participatory action research. Journal of Management Inquiry, 19(4): $305-316$.

Eden, C., \& Huxham, C. 2001. The Negotiation of Purpose in Multi-Organizational Collaborative Groups. Journal of Management Studies, 38(3): 373-391.

Empson, L., Cleaver, I., \& Allen, J. 2013. Managing partners and management professionals: Institutional work dyads in professional partnerships. Journal of Management Studies, 50(5): $808-844$.

Fals-Borda, O. 1991. Remaking knowledge. In O. Fals-Borda \& M. Rahman (Eds.), Action and knowledge: Breaking the monopoly with participation action-research: 146-164. New York, NY: Apex Press.

Franklin, J. S. 2016. A History of Professional Economists and Policymaking in the United States: Irrelevant genius. Routledge.

Freire, P. 2000. Pedagogy of the oppressed. Bloomsbury Publishing.

Friedland, R., \& Alford, R. R. 1991. Bringing society back in: Symbols, practices, and institutional contradictions. In W. W. Powell \& P. J. DiMaggio (Eds.), The new institutionalism in organizational analysis: 232-63. Chicago: University of Chicago Press.

Garud, R., Jain, S., \& Kumaraswamy, A. 2002. Institutional entrepreneurship in the sponsorship of common technological standards: The case of Sun Microsystems and Java. Academy of Management Journal, 45(1): 196-214.

Gawer, A., \& Phillips, N. 2013. Institutional work as logics shift: The case of Intel's transformation to platform leader. Organization Studies, 34(8): 1035-1071. 
Gehman, J., Trevino, L., \& Garud, R. 2013. Values work: A process study of the emergence and performance of organizational values practices. Academy of Management Journal, 56(1): 84-112.

Giddens, A. 1984. The constitution of society: Outline of the theory of structuration. Cambridge, UK: Polity Press.

Goldberg, J. 2015, October 27. Why the "family wars" will never end. New York Post. http://nypost.com/2015/10/27/why-the-family-wars-will-never-end/.

Goodrick, E., \& Reay, T. 2010. Florence Nightingale endures: Legitimizing a new professional role identity. Journal of Management Studies, 47(1): 55-84.

Granqvist, N., \& Gustafsson, R. In press. Temporal institutional work. Academy of Management Journal.

Greenwood, D. J., Whyte, W. F., \& Harkavy, I. 1993. Participatory action research as a process and as a goal. Human Relations, 46(2): 175-192.

Greenwood, R., Raynard, M., Kodeih, F., Micelotta, E. R., \& Lounsbury, M. 2011. Institutional complexity and organizational responses. The Academy of Management Annals, 5(1): $317-371$.

Greenwood, R., \& Suddaby, R. 2006a. Institutional entrepreneurship in mature fields: The big five accounting firms. Academy of Management Journal, 49(1): 27-48.

Greenwood, R., \& Suddaby, R. 2006b. Institutional entrepreneurship in mature fields: The Big Five accounting firms. Academy of Management Journal, 49(1): 27-48.

Greenwood, R., Suddaby, R., \& Hinings, C. R. 2002. Theorizing change: The role of professional associations in the transformation of institutionalized fields. Academy of Management Journal, 45(1): 58-80. 
Hardy, C., Lawrence, T. B., \& Grant, D. 2005. Discourse and collaboration: The role of conversations and collective identity. Academy of Management Review, 30(1): 58-77.

Hawkesworth, M. 2003. Congressional enactments of race-gender: Toward a theory of racedgendered institutions. American Political Science Review, 97(04): 529-550.

Heaphy, E. D. 2013. Repairing breaches with rules: Maintaining institutions in the face of everyday disruptions. Organization Science, 24(5): 1291-1315.

Helfen, M., \& Sydow, J. 2013. Negotiating as institutional work: The case of labour standards and international framework agreements. Organization Studies, 34(8): 1073-1098.

Helms, W. S., Oliver, C., \& Webb, K. 2012. Antecedents of settlement on a new institutional practice: Negotiation of the ISO 26000 standard on social responsibility. Academy of Management Journal, 55(5): 1120-1145.

Hiatt, S. R., Sine, W. D., \& Tolbert, P. S. 2009. From Pabst to Pepsi: The deinstitutionalization of social practices and the creation of entrepreneurial opportunities. Administrative Science Quarterly, 54(4): 635-667.

Hinings, C. R., \& Greenwood, R. 2002. Disconnects and consequences in organization theory? Administrative Science Quarterly, 47(3): 411-421.

Hirsch, P. M., \& Bermiss, Y. S. 2009. Institutional "dirty" work: Preserving institutions through strategic decoupling. In T. B. Lawrence, R. Suddaby, \& B. Leca (Eds.), Institutional work: Actors and agency in institutional studies of organizations: 262-283. Cambridge, UK: University of Cambridge Press.

Hoffman, A. J., \& Jennings, P. D. 2015. Institutional Theory and the Natural Environment Research in (and on) the Anthropocene. Organization \& Environment, 28(1): 8-31. 
Huxham, C., \& Vangen, S. 1996. Working together: Key themes in the management of relationships between public and non-profit organizations. International Journal of Public Sector Management, 9(7): 5-17.

Jarzabkowski, P., Matthiesen, J., \& Van de Ven, A. H. 2009. Doing which work? A practice approach to institutional pluralism. In T. B. Lawrence, R. Suddaby, \& B. Leca (Eds.), Institutional work: Actors and agency in institutional studies of organizations: 284 315. Cambridge, UK: University of Cambridge Press.

Jones, C., \& Massa, F. G. 2013. From novel practice to consecrated exemplar: Unity Temple as a case of institutional evangelizing. Organization Studies, 34(8): 1099-1136.

Kemmis, S., \& McTaggart, R. 2005. Participatory action research: Communicative action and the public sphere. In N. K. Denzin \& Y. S. Lincoln (Eds.), The SAGE handbook of qualitative research (3rd ed.): 559-604. London, UK: SAGE.

Kitchener, M., \& Mertz, E. 2012. Professional projects and institutional change in healthcare: The case of American dentistry. Social Science \& Medicine, 74(3): 372-380.

Knox-Hayes, J., \& Levy, D. L. 2011. The politics of carbon disclosure as climate governance. Strategic Organization, 9(1): 91-99.

Koschmann, M. A., Kuhn, T. R., \& Pfarrer, M. D. 2012. A communicative framework of value in cross-sector partnerships. Academy of Management Review, 37(3): 332-354.

Kraatz, M. S., \& Block, E. S. 2008. Organizational implications of institutional pluralism. The Sage Handbook of Organizational Institutionalism, 840: 243-275.

Latour, B. 1987. Science in action: How to follow scientists and engineers through society. Cambridge, MA: Harvard University Press. 
Latour, B. 2005. Reassembling the social: an introduction to actor-network-theory. Oxford: Oxford University Press.

Latour, B., \& Woolgar, S. 1986. Laboratory life: The construction of scientific facts. Princeton, NJ: Princeton University Press.

Lawrence, T. B., \& Dover, G. 2015. Place and Institutional Work: Creating Housing for the Hard-to-house. Administrative Science Quarterly, 60(3): 371-410.

Lawrence, T. B., \& Suddaby, R. 2006. Institutions and institutional work. In S. R. Clegg, C. Hardy, T. B. Lawrence, \& W. R. Nord (Eds.), Handbook of organization studies (2nd ed.): 215-254. London: Sage.

Lawrence, T. B., Suddaby, R., \& Leca, B. 2009. Introduction: Theorizing and studying institutional work. In T. B. Lawrence, R. Suddaby, \& B. Leca (Eds.), Institutional work: Actors and agency in institutional studies of organizations: 1-27. Cambridge, UK: University of Cambridge Press.

Lee, J., \& Barro, R. J. 2001. Schooling quality in a cross-section of countries. Economica, 68(272): 465-488.

Leung, A., Zietsma, C., \& Peredo, A. M. 2014. Emergent identity work and institutional change: The "quiet" revolution of Japanese middle-class housewives. Organization Studies, 35(3): 423-450.

Lok, J., \& de Rond, M. 2013. On the plasticity of institutions: Containing and restoring practice breakdowns at the Cambridge University Boat Club. Academy of Management Journal, 56(1): 185-207.

Lounsbury, M. 2007. A tale of two cities: Competing logics and practice variation in the professionalizing of mutual funds. Academy of Management Journal, 50: 289-307. 
Lounsbury, M., \& Hirsch, P. M. 2010. Markets on trial: The economic sociology of the U.S. financial crisis. Bingley, UK: Emerald Group Publishing.

Maguire, S., \& Hardy, C. 2009. Discourse and deinstitutionalization: The decline of DDT. Academy of Management Journal, 52(1): 148-178.

Maguire, S., Hardy, C., \& Lawrence, T. B. 2004a. Institutional entrepreneurship in emerging fields: HIV/AIDS treatment advocacy in Canada. Academy of Management Journal, 47(5): 657-679.

Maguire, S., Hardy, C., \& Lawrence, T. B. 2004b. Institutional entrepreneurship in emerging fields: HIV/AIDS treatment advocacy in Canada. Academy of Management Journal, 47(5): 657-679.

Mair, J., \& Marti, I. 2009. Entrepreneurship in and around institutional voids: A case study from Bangladesh. Journal of Business Venturing, 24(5): 419-435.

Mair, J., Marti, I., \& Ventresca, M. J. 2012. Building inclusive markets in rural Bangladesh: How intermediaries work institutional voids. Academy of Management Journal, 55(4): 819-850.

Malsch, B., \& Gendron, Y. 2013. Re-theorizing change: Institutional experimentation and the struggle for domination in the field of public accounting. Journal of Management Studies, 50(5): 870-899.

March, J. G., \& Olsen, J. P. 1976. Ambiguity and choice in organizations. Bergen, Norway: Universitetsforlaget.

Martí, I., \& Fernández, P. 2013. The Institutional Work of Oppression and Resistance: Learning from the Holocaust. Organization Studies, 34(8): 1195-1223. 
Mastrofski, S., \& Parks, R. B. 1990. Improving observational studies of police. Criminology, 28(3): 475-496.

McIntyre, A. 2008. Participatory action research: Qualitative research methods. Thousand Oaks, CA: SAGE.

McPherson, C. M., \& Sauder, M. 2013. Logics in action: Managing institutional complexity in a drug court. Administrative Science Quarterly, 58(2): 165-196.

Merton, R. K. 1968. The Matthew effect in science. Science, 159(3810): 56-63.

Meyer, R. E., Höllerer, M. A., Jancsary, D., \& Van Leeuwen, T. 2013. The visual dimension in organizing, organization, and organization research: Core ideas, current developments, and promising avenues. The Academy of Management Annals, 7(1): 489-555.

Micelotta, E. R., \& Washington, M. 2013. Institutions and maintenance: The repair work of Italian professions. Organization Studies, 34(8): 1137-1170.

Monteiro, P., \& Nicolini, D. 2015. Recovering materiality in institutional work: Prizes as an assemblage of human and material entities. Journal of Management Inquiry, 24(1): 6181.

Munir, K. A. 2011. Financial Crisis 2008-2009: What Does the Silence of Institutional Theorists Tell Us? Journal of Management Inquiry, 20(2): 114-117.

Munir, K. A., \& Phillips, N. 2005. The birth of the "Kodak moment”: Institutional entrepreneurship and the adoption of new technologies. Organization Studies, 26(11): $1665-1687$.

Nicolai, A., \& Seidl, D. 2010. That's Relevant! Different Forms of Practical Relevance in Management Science. Organization Studies, 31(9-10): 1257-1285. 
Nicolini, D., \& Monteiro, P. In press. The practice approach: For a praxeology of organizational and management studies. In H. Tsoukas \& A. Langley (Eds.), The SAGE Handbook of Process Organization Studies. London, UK: SAGE.

Oliver, C. 1991. Strategic responses to institutional processes. Academy of Management Review, 16(1): 145-179.

Oliver, C. 1992. The antecedents of deinstitutionalization. Organization Studies, 13(4): 563588.

Orlikowski, W. J., \& Scott, S. V. 2008. Sociomateriality: challenging the separation of technology, work and organization. The Academy of Management Annals, 2(1): 433474.

Ospina, S., Dodge, J., Foldy, E. G., \& Hofmann-Pinilla, A. 2008. Taking the action turn: Lessons from bringing participation to qualitative research. The Sage Handbook of Action Research: Participative Inquiry and Practice, 420-434.

Pache, A.-C., \& Santos, F. 2013. Inside the hybrid organization: Selective coupling as a response to competing institutional logics. Academy of Management Journal, 56(4): 972-1001.

Peng, M. W., Wang, D. Y. L., \& Jiang, Y. 2008. An institution-based view of international business strategy: a focus on emerging economies. Journal of International Business Studies, 39(5): 920-936.

Perkmann, M., \& Spicer, A. 2007. 'Healing the Scars of History’: Projects, Skills and Field Strategies in Institutional Entrepreneurship. Organization Studies, 28(7): 1101-1122.

Perkmann, M., \& Spicer, A. 2008. How are management fashions institutionalized? The role of institutional work. Human Relations, 61(6): 811-844. 
Pinch, T. J. 2008. Technology and institutions: Living in a material world. Theory and Society, 37(5): 461-483.

Rainelli Weiss, H., \& Huault, I. In press. Business as Usual in Financial Markets? The creation of incommensurables as institutional maintenance work. Organization Studies, 0170840615626463.

Ramirez, C. 2013. "We are being pilloried for something, we did not even know we had done wrong": Quality control and orders of worth in the British audit profession. Journal of Management Studies, 50(5): 845-869.

Raviola, E., \& Norbäck, M. 2013. Bringing technology and meaning into institutional work: Making news at an Italian business newspaper. Organization Studies, 34(8): 1171-1194.

Reay, T., \& Hinings, C. R. 2009. Managing the rivalry of competing institutional logics. Organization Studies, 30(6): 629-652.

Riaz, S., Buchanan, S., \& Bapuji, H. 2011. Institutional work amidst the financial crisis: Emerging positions of elite actors. Organization, 18(2): 187-214.

Rojas, F. 2010a. Power through institutional work: Acquiring academic authority in the 1968 third world strike. Academy of Management Journal, 53(6): 1263-1280.

Rojas, F. 2010b. Power through institutional work: Acquiring academic authority in the 1968 third world strike. Academy of Management Journal, 53(6): 1263-1280.

Ruebottom, T. 2013. The microstructures of rhetorical strategy in social entrepreneurship: Building legitimacy through heroes and villains. Journal of Business Venturing, 28(1): 98-116.

Schatzki, T. R., Knorr-Cetina, K., \& Von Savigny, E. 2001. The practice turn in contemporary theory. Psychology Press. 
Schwarz, O. 2015. The Sound of Stigmatization: Sonic Habitus, Sonic Styles, and Boundary Work in an Urban Slum1. American Journal of Sociology, 121(1): 205-242.

Scott, W. R. 1995. Institutions and organizations, vol. 2. Sage Thousand Oaks, CA.

Scott, W. R., Ruef, M., Caronna, C. A., \& Mendel, P. J. 2000. Institutional change and healthcare organizations : From professional dominance to managed care (1st ed.). Chicago, IL: University Of Chicago Press.

Seitanidi, M. M., Koufopoulos, D. N., \& Palmer, P. 2010. Partnership formation for change: Indicators for transformative potential in cross sector social partnerships. Journal of Business Ethics, 94(1): 139-161.

Selsky, J. W., \& Parker, B. 2005. Cross-sector partnerships to address social issues: Challenges to theory and practice. Journal of Management, 31(6): 849-873.

Seo, M.-G., \& Creed, W. E. D. 2002. Institutional contradictions, praxis, and institutional change: A dialectical perspective. Academy of Management Review, 27(2): 222-247.

Singh, J., \& Jayanti, R. K. 2013. When institutional work backfires: Organizational control of professional work in the pharmaceutical industry. Journal of Management Studies, 50(5): 900-929.

Slager, R., Gond, J.-P., \& Moon, J. 2012. Standardization as institutional work: The regulatory power of a responsible investment standard. Organization Studies, 33(5-6): 763-790.

Smets, M., \& Jarzabkowski, P. 2013. Reconstructing institutional complexity in practice: A relational model of institutional work and complexity. Human Relations, 66(10): 12791309. 
Smets, M., Jarzabkowski, P., Burke, G. T., \& Spee, P. 2015. Reinsurance Trading in Lloyd's of London: Balancing Conflicting-yet-Complementary Logics in Practice. Academy of Management Journal, 58(3): 932-970.

Smets, M., Morris, T., \& Greenwood, R. 2012. From practice to field: A multilevel model of practice-driven institutional change. Academy of Management Journal, 55(4): 877-904.

Sminia, H. 2011. Institutional continuity and the Dutch construction industry fiddle. Organization Studies, 32(11): 1559-1585.

Soundararajan, V., \& Brammer, S. 2015. Understanding Resource-Deprived Actors' Interaction with Conflicting Institutional Demands. Academy of Management Proceedings, 2015(1): 16488.

Stacey, J. 1993. Good riddance to "the family": A response to David Popenoe. Journal of Marriage and Family, 55(3): 545-547.

Starbuck, W. H. 2003. The origins of organization theory. The Oxford Handbook of Organization Theory, 143-182.

Starkey, K., \& Madan, P. 2001. Bridging the relevance gap: Aligning stakeholders in the future of management research. British Journal of Management, 12(s1): S3-S26.

Stiglitz, J. E. 1999. Formal and informal institutions. In P. Dasgupta \& I. Serageldin (Eds.), Social capital: A multifaceted perspective: 59-68. Washington, DC: The World Bank.

Suddaby, R., \& Viale, T. 2011. Professionals and field-level change: Institutional work and the professional project. Current Sociology, 59(4): 423-442.

Swidler, A. 1986. Culture in action: Symbols and strategies. American Sociological Review, $273-286$. 
Thornton, P. H. 2002. The rise of the corporation in a craft industry: Conflict and conformity in institutional logics. Academy of Management Journal, 45(1): 81-101.

Thornton, P. H., Ocasio, W., \& Lounsbury, M. 2012. The institutional logics perspective: A new approach to culture, structure, and process. Oxford, UK: Oxford University Press.

Torres, C. A. 2014. First Freire: Early Writings in Social Justice Education. Teachers College Press.

Toubiana, M., \& Zietsma, C. forthcoming. The Message is on the Wall? Emotions, Social Media and the Dynamics of Institutional Complexity. Academy of Management Journal, amj.2014.0208.

Tracey, P. In press. Spreading the word: The microfoundations of institutional persuasion and conversion. Organization Science.

Tracey, P., Phillips, N., \& Jarvis, O. 2010. Bridging institutional entrepreneurship and the creation of new organizational forms: A multilevel model. Organization Science, 22(1): $60-80$.

Tracey, P., Phillips, N., \& Jarvis, O. 2011. Bridging institutional entrepreneurship and the creation of new organizational forms: A multilevel model. Organization Science, 22(1): $60-80$.

Trank, C. Q., \& Washington, M. 2009. Maintaining an institution in a contested organizational field: The work of AACSB and its constituents. In T. B. Lawrence, R. Suddaby, \& B. Leca (Eds.), Institutional work: Actors and agency in institutional studies of organizations: 236-261. Cambridge, UK: University of Cambridge Press. 
Upshur, R. E. G., VanDenKerkhof, E. G., \& Goel, V. 2001. Meaning and measurement: an inclusive model of evidence in health care. Journal of Evaluation in Clinical Practice, 7(2): 91-96.

Van Wijk, J., Stam, W., Elfring, T., Zietsma, C., \& Den Hond, F. 2013. Activists and Incumbents Structuring Change: The Interplay of Agency, Culture, and Networks in Field Evolution. Academy of Management Journal, 56(2): 358-386.

Voronov, M., \& Vince, R. 2012. Integrating emotions into the analysis of institutional work. Academy of Management Review, 37(1): 58-81.

Walsh, J. P., Meyer, A. D., \& Schoonhoven, C. B. 2006. A future for organization theory: Living in and living with changing organizations. Organization Science, 17(5): 657-671.

Whittington, R. 2006. Completing the practice turn in strategy research. Organization Studies, 27(5): 613-634.

Wijen, F., \& Ansari, S. 2007. Overcoming Inaction through Collective Institutional Entrepreneurship: Insights from Regime Theory. Organization Studies, 28(7): 10791100.

Wright, A., \& Zammuto, R. 2013a. Creating opportunities for institutional entrepreneurship: The Colonel and the Cup in English County Cricket. Journal of Business Venturing, 28(1): $51-68$.

Wright, A., \& Zammuto, R. 2013b. Wielding the Willow: Processes of Institutional Change in English County Cricket. Academy of Management Journal, 56(1): 308-330.

Wright, A., Zammuto, R., \& Liesch, P. 2015. Maintaining the values of a profession: Institutional work and moral emotions in the emergency department. Academy of Management Journal, amj.2013.0870. 
Zald, M. N., \& Lounsbury, M. 2010. The wizards of oz: Towards an institutional approach to elites, expertise and command posts. Organization Studies, 31(7): 963-996.

Zhou, X. 1993. The Dynamics of Organizational Rules. American Journal of Sociology, 98(5): $1134-66$.

Zietsma, C., \& Lawrence, T. B. 2010. Institutional work in the transformation of an organizational field: The interplay of boundary work and practice work. Administrative Science Quarterly, 55(2): 189-221.

Zietsma, C., \& McKnight, B. 2009a. Building the iron cage: institutional creation work in the context of competing proto-institutions. In T. B. Lawrence, R. Suddaby, \& B. Leca (Eds.), Institutional work: Actors and agency in institutional studies of organizations: 143. Cambridge: Cambridge University Press.

Zietsma, C., \& McKnight, B. 2009b. Building the iron cage: Institutional creation work in the context of competing proto-institutions. In T. B. Lawrence, R. Suddaby, \& B. Leca (Eds.), Institutional work: Actors and agency in institutional studies of organizations: 143-177. Cambridge, UK: University of Cambridge Press.

Zilber, T. B. 2007. Stories and the discursive dynamics of institutional entrepreneurship: The case of Israeli high-tech after the bubble. Organization Studies, 28(7): 1035-1054.

Zilber, T. B. 2009. Institutional maintenance as narrative acts. In T. B. Lawrence, R. Suddaby, \& B. Leca (Eds.), Institutional work: Actors and agency in institutional studies of organizations: 205-235. Cambridge, UK: University of Cambridge Press.

Zilber, T. B. 2013. Institutional logics and institutional work: Should they be agreed? In M. Lounsbury \& E. Boxenbaum (Eds.), Institutional logics in action, vol. 39. Bingley, UK: Emerald Group. 
Zuckerman, E. W. 2010. What if we had been in charge? The sociologist as builder of rational institutions. In M. Lounsbury \& P. M. Hirsch (Eds.), Markets on trial: The economic sociology of the U.S. financial crisis, vol. B: 359-378. Bingley, UK: Emerald Group Publishing. 